Author version: J. Mar. Syst., vol.137; 2014; 35-46

\title{
Nitrate reducing activity pervades surface waters during upwelling
}

Sheryl Oliveira Fernandes ${ }^{\mathrm{a}}$, Reena Halarnekar ${ }^{\mathrm{a}}$, Ashish Malik ${ }^{\mathrm{a}, \dagger}$, Vijitha Vijayanª ${ }^{\mathrm{a}}$, Sandesh Varik ${ }^{\mathrm{a}}$, Ritu Kumari ${ }^{\mathrm{a}}$, Jineesh VK ${ }^{\mathrm{b}}$, Manguesh U. Gauns ${ }^{\mathrm{a}}$, Shanta Nair ${ }^{\mathrm{a}}$, P. A. LokaBharathi ${ }^{\mathrm{a}, *}$

${ }^{a}$ Biological Oceanography Division, CSIR - National Institute of Oceanography, Dona Paula, Goa, India - 403004.

${ }^{\mathrm{b}}$ CSIR-National Institute of Oceanography, Regional Centre, PB 1913, Cochin, Kerala, India - 682018.

${ }^{\dagger}$ Present address: Department of Biogeochemical Processes, Max Planck Institute for Biogeochemistry, Hans-Knoell- Str. 10, 07745 Jena, Germany.

* Corresponding author. Tel.: +91-832-2450281; Fax: +91-832-2450602

E-mail address: loka@nio.org, lokabharathiponnapakkam@gmail.com (P. A. LokaBharathi)

\section{ABSTRACT}

Nitrate reducing activity (NRA) is known to be mediated by microaerophilic to anaerobic bacteria and generally occurs in the sub-surface waters. However, we hypothesize that NRA could become prominent in the surface waters during upwelling. Hence, we examined nitrification and nitrate reduction along with hydrographic and environmental parameters off Trivandrum and Kochi, south-west-India in June 2010. Shoaling isolines of temperature, density, and nutrients revealed the onset of upwelling off Trivandrum. Shoaling of these signatures was absent in the northern transect off Kochi. The degree of nutrient consumption (DNC) was low emphasizing the presence of newly upwelled water off Trivandrum. A significant increase in NRA $(\mathrm{df}=1, \mathrm{p}<0.05)$ was observed off Trivandrum than at Kochi. Moreover, as hypothesized, NRA at Trivandrum was pronounced at the surface with a maximum rate of $0.85( \pm 0.02) \mu \mathrm{mol} \mathrm{L}^{-1} \mathrm{~h}^{-1}$ nearshore which was $\sim 29 \mathrm{x}$ higher than at Kochi. Further, an inverse relationship between NRA and $\mathrm{NO}_{3}{ }^{-}$concentration $(\mathrm{n}=34, \mathrm{r}=-0.415, \mathrm{p}<0.01)$ suggested transformation of the upwelled nutrient. Nitrification/NRA was $\sim 10 \mathrm{x}$ lower at 0.28 off Trivandrum indicating a discernible shift towards reduction. Such contribution from bacterial activity could be a response towards restoration of homeostasis.

Keywords: Bacteria; coastal waters; nitrification; nitrate reduction; nutrients; upwelling 


\section{Introduction}

Upwelling is a process which occurs in three sequential stages - (1) the offshore transport of surface water and its replacement by cold, nutrient rich sub-surface water (Krishna, 2008) (2) the productive phase wherein an increase in phytoplankton standing stock (Sawant and Madhupratap, 1996; Habeebrehman et al., 2008) occurs due to nitrate and ammonium uptake while enhanced bacterial production (Carvalho and Gonzalez-Rodriguez, 2004) is a result of heterotrophic carbon assimilation and (3) the oligotrophic relaxing or waning phase which results in nutrient depletion accompanied by decrease in phytoplankton biomass (Rodriguez et al., 1992). In the Indian Ocean region, the main upwelling zone is located along the Somali coast in the western Arabian Sea (Schott and McCreary, 2001). The south-west coast of India also experiences seasonal upwelling during the summer monsoon (June-September). Analyses of hydrographic characteristics have revealed the presence of strong upwelling signatures off the southern tip of the Indian peninsula by May which progress towards the north with time (Antony and Unnikrishnan, 1987). The upwelling phenomenon along the south west coast of India is highly localised with different forcing mechanisms operating at various latitudes. These are longshore wind stress, coastally trapped Kelvin waves and the offshore propagating Rossby waves (Smitha, 2010).

Until now, some of the upwelling related studies in the coastal Arabian Sea have focused on observing hydrographic signatures to delineate the process (Muraleedharan and Prasannakumar, 1996; Jyothibabu et al., 2008), the commencement and cessation of upwelling (Antony and Unnikrishnan, 1987) and, biological response to physical and chemical changes in the environment (Madhupratap et al., 1990; Jyothibabu et al., 2008; Habeebrehman et al., 2008; Subina et al., 2012). So far, very little attention had been given to appreciate the contribution made by bacteria and the different geomicrobial processes they mediate. In the microbial grid of interactions, the nitrogen $(\mathrm{N})$ cycle is an important hub as far as upwelling is concerned as transformation of the element into various oxidation states can affect key ecosystem processes such as decomposition and primary production. Nitrogen is one of the main limiting nutrients in the oceans (Dufour et al., 1999). Increased concentration of $\mathrm{NO}_{3}^{-}$from upwelled waters in the euphotic zone supports higher primary production which in turn could cascade to the tertiary trophic level. Moreover, low-oxygen (minimum values close to the hypoxic threshold of $1.4 \mathrm{~mL}$

$\mathrm{L}^{-1}$ ) (Roegner et al., 2011) and high $\mathrm{NO}_{3}{ }^{-}$content (typically between 5 and $15 \mu \mathrm{mol} \mathrm{L}{ }^{-1}$ ) in freshly upwelled waters (Smith and Codispoti, 1980) has a potential to induce occurrence of alternate 
respiratory pathways like denitrification. As upwelling progresses, nutrient draw-down results in an $\mathrm{N}$ deficit in the water column. During the waning stage of upwelling, a rapid depletion of oxygen in the coastal waters due to degradation of high phytoplankton biomass could further intensify dissimilatory pathways in the $\mathrm{N}$ cycle i.e. nitrate reduction and denitrification. Though a few reports on $\mathrm{N}$ transformations are available from upwelling regions elsewhere (Alvarez-Salgado et al., 1996; Chen et al., 2004; Kuypers et al., 2005; Sohm et al., 2011; Fernandez and Farías, 2012), there is a lack of information from the Indian Ocean region.

In this study, we focused on the first of the three sequential phases of upwelling. We aimed to understand the following (i) delineating the characteristics and intensity of upwelling in the waters off Trivandrum (southern-most location) during June, 2010 and compare it with Kochi located towards the north (ii) to understand whether nutrient draw-up during upwelling causes a discernable shift towards reduction in the $\mathrm{N}$ cycle i.e. nitrate reduction activity prevails over nitrification (iii) examine the environmental factors influencing the dominant process (nitrification v/s nitrate reduction) in freshly upwelled waters and most importantly (iv) to verify the hypothesis that nitrate reducing activity (NRA) could become prominent even in the surface waters during upwelling. Hydrographic observations in the present study indicated the commencement of upwelling off Trivandrum and its absence off Kochi. The pre-dominance of NRA in the waters off Trivandrum strengthens our hypothesis of a discernable shift towards reduction in the $\mathrm{N}$ cycle and its spread in the surface waters. Though previous research has shown the dominance of $\mathrm{NO}_{3}{ }^{-}$reduction in upwelled waters, we have been able to delineate the microbial contribution to such a shift in response to changes in the water column chemistry for the first time.

\section{Methods}

\subsection{Study area and sampling}

Stratified water column sampling was carried out along two cross shelf transects located off Trivandrum and Kochi, south-west coast of India (Fig. 1; Table S1). Water samples were collected using 10-L Go Flow bottles (General Oceanics, Miami, FL, USA) mounted on to a Conductivity Temperature Depth (CTD; Sea-Bird Electronics, SBE 911 Plus, USA) rosette onboard FORV Sagar Sampada (cruise no. 276; June, 2010). 


\subsection{Physico-chemical parameters}

The vertical profile of temperature, salinity, density, and depth at each station was collected from the respective sensors of the CTD profiler. Hydrogen ion concentration $(\mathrm{pH})$ at each section was measured using an Orion 4-Star Plus Benchtop pH/ISE Meter (Thermo Scientific, Beverly, MA, USA) after calibration with standard buffers ( $\mathrm{pH}$ 4, 6.9 and 9; Merck). Dissolved oxygen (DO) content in the ambient water was determined using the traditional Winkler's titration (Winkler, 1888) method. A dosimeter (Metrohm 785 DMP Titrino, Switzerland) was used for the analysis. Nutrients (ammonium, nitrite, nitrate, phosphate and silicate) analyses were done onboard using a segmented flow SKALAR auto-analyzer (Skalar, Breda, The Netherlands; Model 51001-1) as described by Wurl (2009).

\subsection{Microbiological studies}

Bacterial productivity (BP) was determined by the incorporation of the nucleoside ${ }^{3} \mathrm{H}$-thymidine into bacterial DNA (Smith and Azam, 1992). Seawater was collected in sterile polycarbonate bottles. Filtered samples $(1.5 \mathrm{~mL})$ were spiked with ${ }^{3} \mathrm{H}$-thymidine $\left({ }^{3} \mathrm{H}-\mathrm{TdR}\right)$ at a final concentration of $10 \mathrm{nM}$ (specific activity $=52 \mathrm{Ci} \mathrm{mmol}^{-1}, \mathrm{BARC}$, Mumbai) and incubated under in situ conditions in the dark on deck for $2 \mathrm{~h}$. Concentrations in kinetic experimental set up showed that isotopic dilution was negligible when using $10 \mathrm{nM}$ thymidine. TdR incorporation was terminated by addition of 5\% TCA (Trichloroacetic acid). The samples were kept at $4{ }^{\circ} \mathrm{C}$ for $30 \mathrm{~min}$ prior to centrifugation. The tubes were centrifuged for $10 \mathrm{~min}$ at $16000 \mathrm{xg}$ after which the supernatant was pipetted and discarded. The pellet was washed with 5\% TCA and vortexed briefly. Centrifugation of washed samples was repeated followed by removal of the supernatant. A $500 \mu \mathrm{L}$ volume of scintillation cocktail was added to the samples which were left to stand overnight. Radioactivity was measured with a liquid scintillation counter (Model no. LS6500; Beckman Coulter International, Nyon, Switzerland) with external standards. BP was calculated as moles of TdR incorporated into DNA. The values obtained have been expressed as pmol $\mathrm{L}^{-1} \mathrm{~h}^{-1}$.

The method of Hobbie et al. (1977) was used for the enumeration of total bacterial cells (TC) by epifluorescence microscopy. An aliquot of $5 \mathrm{~mL}$ water sample was fixed using $250 \mu \mathrm{L}$ of buffered formalin ( $2 \%$ final concentration). Aerobic viable cells (TVC_a) and anaerobic viable cells (TVC_an) were enumerated separately according to Kogure et al. (1984). Five millilitres of seawater samples for 
TVC_a analysis were amended with $0.001 \%$ final concentration of yeast extract and $0.0016 \%$ final concentration of antibiotic cocktail solution containing piromedic, pipemedic and nalidixic acid which were in the ratio 1:1:1. Samples were incubated statically in the dark for $6 \mathrm{~h}$. For enumerating TVC_an, in addition to yeast extract and antibiotic cocktail, $\mathrm{Na}_{2} \mathrm{~S} 9 \mathrm{H}_{2} \mathrm{O}$ was added as a reductant at a final concentration of $0.125 \%$ (LokaBharathi et al., 1999) before incubation. At the end of the incubation, all the aliquots were fixed with $2 \%$ buffered formalin. For TC and TVC, one $\mathrm{mL}$ of sub-sample was filtered over a $0.2 \mu \mathrm{m}$ black Isopore polycarbonate filter paper (Millipore Corp., MA, USA) and stained with acridine orange (final concentration $0.01 \% \mathrm{w} / \mathrm{v}$ ). The samples were incubated for $2 \mathrm{~min}$ and then filtered. At the onshore laboratory, bacterial cells retained on the filter papers were counted using Nikon 50i epifluorescence microscope equipped with a 100X oil immersion objective. Cells were counted from 10-100 microscopic fields and were expressed as cells $\mathrm{L}^{-1}$.

We adopted a cultivation-based approach to enumerate the abundance of total heterotrophic bacteria (THB). Such an approach suffers from well-accepted problems like incubation conditions, slow growth of organisms, low retrievability, etc. However, it has been shown that in coastal waters having considerable dissolved organic carbon levels, bacterial species able to form colonies on solid media dominant the bacterioplankton community (Simu et al., 2005). Hence, they can be grown to a detectable level to ascertain their presence in the environment. The THB were thus enumerated on medium prepared using seawater amended with $0.1 \%$ nutrient broth (HiMedia Laboratories Ltd., India). After dissolution of the broth, $\mathrm{pH}$ of the medium was adjusted to 8.2. Agar at a final concentration of $1.5 \%$ was then added before autoclaving. A $20 \mu \mathrm{L}$ inoculum was used to spread plate on to the set nutrient agar plates. The plates were incubated at room temperature $\left(28 \pm 2{ }^{\circ} \mathrm{C}\right)$ for 5 days. Bacterial counts were taken as colony forming units $(\mathrm{CFU}) \mathrm{L}^{-1}$.

Nitrifiers were enumerated by the most probable number (MPN) method of Alexander and Clark (1965). Five $\mathrm{mL}$ of Winogradsky's medium (Rodina, 1972) containing $\mathrm{NH}_{4} \mathrm{Cl}$ at a final concentration of $2 \mathrm{mM}$ (Krishnan et al., 2008) was dispensed in sterile $15 \mathrm{~mL}$ screw capped tubes. One $\mathrm{mL}$ sample was inoculated in triplicate in the nitrifying medium to yield a $10^{-1}$ dilution. Subsequent dilutions (up to $10^{-8}$ ) were prepared in triplicates. The culture tubes were incubated in the dark for a period of 15 days at $28 \pm$ $2{ }^{\circ} \mathrm{C}$. After incubation, the tubes were tested for the presence of $\mathrm{NO}_{2}{ }^{-}$and/or $\mathrm{NO}_{3}{ }^{-}$. The combinations of positive and negative tubes were scored and MPN was assessed from McCready's table (Rodina, 1972). 
Numbers of nitrate reducing bacteria (NRB) were also enumerated by the most probable number (MPN) technique. The culture medium was prepared using substrates required for the growth of denitrifying bacteria as suggested by Michotey et al. (2000) and Fernandes et al. (2013). The final concentration of $\mathrm{NO}_{3}{ }^{-} \mathrm{N}$ in the medium was $40 \mu \mathrm{mol} \mathrm{L}{ }^{-1}$. Culture vials $(22 \mathrm{~mL})$ were filled with the medium almost to the brim to maintain microaerophilic conditions. With the addition of innocula in 1 $\mathrm{mL}$ aliquot, the vials were filled to the brim. The tubes were thus inoculated in triplicates at each

dilution up to $10^{-10}$. The culture tubes were sealed with butyl stoppers and incubated in the dark at $28 \pm 2$ ${ }^{\circ} \mathrm{C}$ for one week. Positive tubes were scored based on $\mathrm{NO}_{3}{ }^{-}$consumption and the MPN was assessed as described earlier. Nitrifier and NRB counts have been expressed as MPN cells $\mathrm{L}^{-1}$.

\subsection{Biological analysis}

Particulate matter retained on a Whatmann GF/F, $0.7 \mu \mathrm{m}$ pore size, after filtering $1 \mathrm{~L}$ seawater was used for pigment (chlorophyll $a$ and phaeopigments) analysis. To extract the pigments, the filters were placed into $15 \mathrm{~mL}$ screw-top tubes and treated with $10 \mathrm{~mL}$ of $90 \%$ acetone. After a period of $24 \mathrm{~h}$ in darkness at $-20{ }^{\circ} \mathrm{C}$, the extract was measured fluorometrically (UNESCO, 1994). The samples were acidified to degrade the chlorophyll to phaeopigments (i.e. phaeophytin). The readings before and after acidification were then used to calculate concentrations of both chlorophyll $a(\mathrm{Chl} a)$ and phaeopigment.

For the analyses of phytoplankton abundance, $250 \mathrm{~mL}$ of seawater was preserved with Lugol's iodine ( $1 \%$ final concentration). Samples were then concentrated to $20 \mathrm{~mL}$ using settling and siphoning procedure. Abundance of phytoplankton species were enumerated in $1 \mathrm{~mL}$ of sample (in duplicate) using a Sedgwick-Rafter chamber mounted onto an Olympus Inverted Microscope (IX51, Japan; 200$400 \mathrm{X}$ magnification). The phytoplankton abundance is expressed as cells $\mathrm{L}^{-1}$.

Samples for mesozooplankton were collected using a vertically operated multiple plankton net system (Hydro-Bios, Germany; mouth area $0.25 \mathrm{~m}^{2}$, mesh width $200 \mu \mathrm{m}$ ) equipped with an inbuilt flow meter and electronic depth sensor. Samples were preserved using $4 \%$ borax buffered formaldehyde. Prior to analysis, the samples were split using a Folsom's splitter and then examined under a stereozoom microscope (Nikon; SMZ1000; 80x). The mesozooplankton abundance is expressed as individuals per cubic meter. 


\subsection{Degree of nutrient consumption}

Chen et al. (2004) have used the Degree of Nutrient Consumption (DNC) in upwelled waters to evaluate the upwelling process in Nanwan Bay, Taiwan. As hydrographic signatures indicated occurrence of upwelling off Trivandrum, we used the equation of Chen et al. (2004) to determine the relative aging status of upwelled water as follows:

$$
D N C=\frac{(0.7 \times \mathrm{Chl} a)}{\left(\mathrm{NO}_{3}^{-}+\mathrm{NO}_{2}^{-}+0.7 \times \mathrm{Chl} a\right)}
$$

where, the constant 0.7 is a conversion factor between Chl $a$ (in $\mu \mathrm{g} \mathrm{L}^{-1}$ ) and inorganic nitrogen (in $\mu \mathrm{mol}$ $\left.\mathrm{L}^{-1}\right)$.

The rationale behind the above equation described by Chen et al. (2004) is that sub-surface or newly upwelled waters contain little or no Chl $a$ resulting in low DNC. On the other hand, the DNC is $\approx 1$ after most nutrients are converted to organic form $(\mathrm{Chl} a)$ in the euphotic zone.

\subsection{Net nitrification and nitrate reduction rate measurements}

To measure net nitrification rates, $10 \mathrm{~mL}$ seawater sample was dispensed in $15 \mathrm{~mL}$ screw cap tubes. The samples were amended with $10 \mathrm{mmol} \mathrm{L}^{-1}$ sodium chlorate to inhibit the oxidation of nitrite (Gilbert et al., 1997). Triplicates were maintained at each time interval of $0,1.5$ and $3 \mathrm{~h}$. The tubes were incubated in the dark and at room temperature. Incubations were terminated using $\mathrm{HgCl}_{2}$ at a final concentration of $10 \mathrm{mmol} \mathrm{L}^{-1}$. The tubes were gently swirled to mix the contents. Nitrification rate was determined from the linear production of $\mathrm{NO}_{2}{ }^{-}$over time. The activity has been expressed as $\mu \mathrm{mol} \mathrm{L}^{-1} \mathrm{~h}^{-}$ 1 .

For determining nitrate reduction, the first step in the denitrification pathway, seawater samples were dispensed in sterile $22 \mathrm{~mL}$ glass vials that were filled almost up to the brim to minimize the diffusion of oxygen from the headspace. The samples were amended with allythiourea at a concentration of $86 \mu \mathrm{mol} \mathrm{L}^{-1}$ to inhibit nitrification (Ginestet et al., 1998). The vials were capped with butyl stoppers and the contents were gently mixed by inverting. The waters off Trivandrum and Kochi had measurable dissolved oxygen content and heterotrophic nitrate reduction was not likely to be deterred by the presence of oxygen (LokaBharathi et al., 1992). Thus, microaerophilic conditions in the vials would not hamper the occurrence of NRA if it was present in situ. Triplicates were maintained at each incubation 
time interval of $0,1.5$ and $3 \mathrm{~h}$. A short incubation period was maintained as our preliminary experiments have shown the inhibitor to be effective for up to $3 \mathrm{~h}$. The vials were incubated under static conditions at room temperature and in the dark. At the end of the incubation period, reactions were terminated using $\mathrm{HgCl}_{2}$ as described above and the tubes were gently inverted to mix the contents. NRA was determined from fall in $\mathrm{NO}_{3}{ }^{-}$concentration over time and the rate has been expressed as $\mu \mathrm{mol} \mathrm{L}{ }^{-1} \mathrm{~h}^{-1}$.

\subsection{Statistical analyses}

Significant differences in nitrification and NRA at both the locations were analysed using analysis of variance (ANOVA) in Analysis tool pack (Microsoft Excel). As, NRA was more pronounced in the upwelled waters off Trivandrum, Pearson's correlation coefficients were used to assess one-to-one relationship between NRA and environmental parameters. Bacterial numbers were $\log _{10}$ transformed before analysis. Significant relationships have been plotted using Cytoscape 2.6.3 software (http://www.cytoscape.org/), which enabled an open-source network visualization. To further establish the combined effect of environmental variables on NRA, we subjected the biotic and abiotic factors to principal component analysis (PCA) using the XLSTAT software version 2012 (Addinsoft, New York, USA). This method provided an ordination of sampling points and variables which were plotted in two dimensions based on the scores in the first two principal components. The results of the ordination analyses were visualized as a bi-plot (Catell, 1966; Gabriel, 1971).

\section{Results}

\subsection{Hydrography}

Physico-chemical signatures (Figs. 2 a-j) clearly indicated upwelling off Trivandrum during the early monsoon period and its absence along the northern transect off Kochi (Figs. 3 a-j). At Trivandrum, prominent signatures providing evidence for the prevalence of upwelling were based on the sea surface temperature anomaly, notably shoaling of the thermocline (Fig. 2a) and occurrence of denser waters at shallower depths towards the coast (Fig. 2b). Movement of seawater with lower $\mathrm{pH}$ ranging from 7.9 - 8 from the deeper offshore water towards the coast was also noticed off Trivandrum (Fig. 2d). This pattern in $\mathrm{pH}$ distribution was absent off Kochi. Dissolved oxygen profiles showed prevalence of low levels of oxygen $\left(\leq 1 \mu \mathrm{mol} \mathrm{L}{ }^{-1}\right)$ in a major part of the sampling area. This low oxygen zone was widespread and extended from a depth $>150 \mathrm{~m}$ at the offshore location to about $25 \mathrm{~m}$ in the nearshore location (Fig. 2e). 
At Kochi, low oxygen-containing waters were observed towards the offshore locations at $>50 \mathrm{~m}$ depth (Fig. 3e). Among nutrients, up-sloping in the isolines of nitrate $\left(15.4 \mu \mathrm{mol} \mathrm{L}{ }^{-1}\right.$; Fig. $\left.2 \mathrm{~h}\right)$, phosphate $(1.3$ $\mu \mathrm{mol} \mathrm{L}{ }^{-1}$, Fig. $\left.2 \mathrm{i}\right)$ and silicate $\left(1.8 \mu \mathrm{mol} \mathrm{L}{ }^{-1}\right.$; Fig. $\left.2 \mathrm{j}\right)$ towards the coast were more pronounced off Trivandrum than at Kochi.

\subsection{Microbiological studies}

Bacterial productivity at both locations was maximum at the nearshore sampling sites and decreased with distance from the coast. At Trivandrum a maximum of $32.00 \pm 0.94 \mathrm{pmol} \mathrm{L}^{-1} \mathrm{~h}^{-1}$ was recorded in the surface waters at station 1 (Table 1). At Kochi, the productivity varied from $0.06 \pm 0.01$ to $7.56 \pm 0.22 \mathrm{pmol} \mathrm{L}^{-1} \mathrm{~h}^{-1}$ (Table 2).

Though the bacterial productivity off Trivandrum was higher as compared to Kochi, number of bacterial cells (TC) were significantly higher (ANOVA, df $=1, \mathrm{p}<8.79 \times 10^{-6}$ ) off Kochi varying between $1.25 \pm 0.70 \times 10^{9}$ cells $\mathrm{L}^{-1}$ to $4.79 \pm 26.8 \times 10^{10}$ cells $\mathrm{L}^{-1}$. The abundance of TVC_a at both locations were in the order of $10^{8}$ cells $\mathrm{L}^{-1}$ whereas the viable anaerobes were higher by one order at Kochi $\left(10^{8}\right.$ cells $\left.\mathrm{L}^{-1}\right)$. Abundance of heterotrophs in the waters off Trivandrum and Kochi was in the order of $10^{7} \mathrm{CFU} \mathrm{L}^{-1}$ (Table 1 and 2). The nitrifiers were significantly higher at Trivandrum $(\mathrm{df}=1, \mathrm{p}<$ $2.74 \times 10^{-8}$ ) (Table 1) than at Kochi (Table 2). A significant difference in NRB abundance was also recorded between both sites $(\mathrm{df}=1, \mathrm{p}<0.005)$ as their abundance off Trivandrum varied between $10^{6-10}$ MPN cells $L^{-1}$ while at Kochi they varied from $10^{7-10}$ MPN cells L ${ }^{-1}$ (Table 2).

\subsection{Biological parameters}

The concentration of chlorophyll $a$ and phaeopigments were generally higher towards the coast at Trivandrum and Kochi decreasing to $<1 \mu \mathrm{g} \mathrm{L}^{-1}$ at the offshore locations (Fig. 4). At Trivandrum, a maximum of $3.75 \mu \mathrm{g} \mathrm{L}^{-1}$ of Chl $a$ and $2.87 \mu \mathrm{g} \mathrm{L}^{-1}$ of phaeopigments content was observed at $25 \mathrm{~m}$ depth (station no. 4). At Kochi, the maximum Chl a concentration was $2.35 \mu \mathrm{g} \mathrm{L}{ }^{-1}$ while $1.30 \mu \mathrm{g} \mathrm{L}^{-1}$ of phaeopigments content was recorded at $25 \mathrm{~m}$ in station 3 .

The Chl a maxima at station 4 in Trivandrum coincided with the phytoplankton maxima of $146 \mathrm{x}$ $10^{3}$ cells $\mathrm{L}^{-1}$. In comparison, the maximum phytoplankton abundance at Kochi was $\sim 3 \mathrm{x}$ lower (Fig. 5). At both locations, the phytoplankton were most abundant towards the coast. The mesozooplankton were 
up to $12 \mathrm{x}$ higher at Kochi (max. 528 ind. $\mathrm{m}^{-3}$ ) as compared to Trivandrum with higher numbers being observed even in the offshore locations (Fig. 5).

\subsection{Degree of nutrient consumption}

The DNC values in the waters off Trivandrum were $<1$ ranging from non-detectable levels to 0.57 (Table 1).

\subsection{Activity measurements}

Nitrate reducing activity off Trivandrum was significantly higher $(\mathrm{df}=1, \mathrm{p}<0.05)$ occurring up to $29 \mathrm{x}$ higher as compared to Kochi. Nitrification rates generally decreased with depth varying from $0.02( \pm 0.00) \mu \mathrm{mol} \mathrm{L}{ }^{-1} \mathrm{~h}^{-1}$ at station $1,25 \mathrm{~m}$ to $0.32( \pm 0.12) \mu \mathrm{mol} \mathrm{L}{ }^{-1} \mathrm{~h}^{-1}$ at the same depth in station 5 (Fig. 6). No significant differences in spatial variability of nitrification were observed at both locations. NRA also exhibited a decreasing trend with depth and distance from the coast. Highest activity of 0.85 $( \pm 0.02) \mu \mathrm{mol} \mathrm{L} \mathrm{L}^{-1} \mathrm{~h}^{-1}$ was recorded in surface waters closest to the coast. Significant relationships between environmental variables and bacterial activities off Trivandrum were observed (Fig. 7a). NRA correlated with a number of upwelling signatures (Fig. 7b) mainly $\mathrm{NO}_{3}{ }^{-}$concentration $(\mathrm{n}=34, \mathrm{r}=-$ 0.415, p < 0.01), Chl $a(\mathrm{r}=0.496, \mathrm{p}<0.001)$, BP $(\mathrm{r}=0.498, \mathrm{p}<0.001)$ and mesozooplankton abundance $(\mathrm{r}=0.702, \mathrm{p}<0.001)$.

At Kochi, there was no clear difference in nitrification or NRA. Interestingly, nitrification activity at the offshore locations (stations $5 \& 6$ ) were below detectable levels (Fig. 6). The highest nitrification and NRA activity of $3.49( \pm 1.86) \mu \mathrm{mol} \mathrm{L}^{-1} \mathrm{~h}^{-1}$ and $3.24( \pm 0.05) \mu \mathrm{mol} \mathrm{L}{ }^{-1} \mathrm{~h}^{-1}$ respectively were recorded at $\geq 25 \mathrm{~m}$ in station 2 .

\subsection{Environmental controls on NRA in upwelled waters}

We used PCA to understand the extent of influence of environmental variables on NRA in upwelled waters. Based on eigenvalues $(>1)$ and the variability explained by each factor, the first eight factors were selected from the PCA (Pearson type; correlation bi-plot) analysis. These factors accounted for $82.7 \%$ of the cumulative variability (Table S2). Factors 1 and 2 explained 33.79 and 12.68\% of the total variance respectively. Our data showed that variables viz., depth, temperature, density, $\mathrm{pH} \mathrm{NO}_{3}{ }^{-}$, $\mathrm{PO}_{4}{ }^{-} \mathrm{SiO}_{2}, \mathrm{Chl} a$, phaeopigments and phytoplankton abundance were correlated to the first component 
(PC1). NRA, $\mathrm{NH}_{4}^{+}$concentration, bacterial productivity, TVC_a and mesozooplankton abundance (Fig. 8a) had positive coordinates along the PC1 axis, which emphasized the clear cluster they made. Nitrification had positive values on PC1 and PC2 axis while all nutrients had negative values on PC2.

A good discrimination of the sampling points in relation to distribution of environmental variables was observed (Fig. 8b). It can be clearly observed that the nearshore sampling points (station 1 \& 2) exhibiting elevated NRA and bacterial productivity were positively correlated to PC1 and grouped together. The sampling point at $25 \mathrm{~m}$ in station 5 was characterized by maximum nitrification activity as seen in the PCA plot (Fig. 8a and b).

\section{Discussion}

The Arabian Sea represents a dynamic ecosystem that is characterized by physico-chemical and biological variability governed by monsoon-driven circulation. Upwelling along the south-west coast of India has been recorded to occur during the summer monsoon (Sarma, 1966; Lathipha and Murthy, 1985; Maheswaran, 2000). Therefore, in June 2010, we conducted water sampling off Trivandrum and Kochi anticipating upwelling signatures in these waters. The results presented here attest the onset of upwelling off Trivandrum during the early monsoon period and its absence along the northern transect off Kochi. Sub-surface isolines of hydrographic signatures like temperature, density, nitrate, phosphate and silicate across the shelf off Trivandrum exhibited gradual shoaling/upsloping towards the coast (Figs. 2a, b, h, i and j) which is consistent with active upwelling. The vertical thermal structure off Trivandrum exhibited fine upsloping of isotherms towards the coast which is evident from the nearshore sea surface temperature being $\sim 3.88^{\circ} \mathrm{C}$ lower than the furthest offshore station. Upsloping of isopycnals within $150 \mathrm{~m}$ were also observed to occur towards the coast. Upwelling is responsible for transporting higher salinity deeper water to the surface. However, in the present study, we recorded lower saline waters towards the coast (Fig. 2c). The formation of a low salinity layer in the nearshore locations off Trivandrum could be attributed to precipitation over the area during the sampling period accompanied by freshwater influx through land runoff. Other than upsloping in isolines of nutrients like phosphate and silicate, shoaling in the isolines of $\mathrm{NO}_{3}{ }^{-}$was also prominent off Trivandrum. The $\mathrm{NO}_{3}$

concentrations in surface waters $(<15 \mathrm{~m})$ was $<8 \mu \mathrm{mol} \mathrm{L}{ }^{-1}$ which is indicative of its uptake by the microbial/phytoplankton community. 
Though the occurrence of upwelling off Trivandrum can be fairly recognized from some hydrographic indicators as mentioned above, rainfall over the region could blur some prominent physico-chemical signatures. Many a time, additional factors like the air-sea exchange of heat affecting temperature, turbulence caused by wind mixing, tidal movements, internal waves and bottom topography affecting both temperature and salinity, extraneous nutrient input into coastal waters through rivers, depletion of upwelled nutrients due to enhanced biological productivity, divergence of water from the upwelling center make it difficult to identify upwelling (Chen et al., 2004). To minimize ambiguities and further substantiate our observations on the occurrence of upwelling off Trivandrum, we estimated DNC (Chen et al., 2004) using the relative percentages of biologically important elements in their inorganic and organic form (Takahashi et al., 1986). The DNC values in waters off Trivandrum were low $\left(<1\right.$; Table 1) indicating the presence of newly upwelled waters wherein nutrients like $\mathrm{NO}_{3}{ }^{-}$ $/ \mathrm{NO}_{2}{ }^{-}$have not yet been converted to organic form $(\mathrm{Chl} a)$ by the phytoplankton community.

The distribution of biological variables also appeared to be influenced by physical forcing. The Chl $a$ values recorded in the waters off Trivandrum were higher (Fig. 4) as compared to Kochi especially towards the nearshore region indicating development of an active phytoplankton community. Though no significant difference in the abundance of the phytoplankton was observed between the two locations (Fig. 5), the phaeopigment concentration in the waters off Trivandrum was much higher $(\mathrm{df}=$ 1, $\mathrm{p}<0.05$ ) as compared to Kochi, more so towards the coast (Fig. 4). Upwelling propelled nutrient injection into the euphotic zone, phytoplankton production and pigment degradation appear to follow a sequential pattern in the nearshore region. This region also exhibited bacterial productivity of up to $32 \pm$ $0.94 \mathrm{pmol} \mathrm{L}^{-1} \mathrm{~h}^{-1}$ (Table 1) which is 10x higher than values reported from the south west coast of India during the summer monsoon (Ramaiah et al., 1996). This observation is in agreement with earlier findings that have shown occurrence of highest bacterial production rates in the initial stages of growth and during the decline of primary production (Carvalho and Gonzalez-Rodriguez, 2004).

Microbial processes regulate the availability of nutrients in the marine environment by balancing extraneous input, remineralization and removal. Coastal upwelling has a significant impact on ecosystem functioning as an episodic supply of nutrients to the euphotic zone can stimulate a rapid increase in phytoplankton abundance. It can also increase competition between phytoplankton and bacteria for nutrient uptake. So far, the role of bacteria in mediating biogeochemical processes in the Arabian Sea upwelling zone have not been fully understood. To gain a deeper insight into inorganic $\mathrm{N}$ 
transformations in upwelled and non-upwelled waters, we probed two components of the $\mathrm{N}$ cycle nitrification and NRA. The reductive pathway is often enhanced following pulses of $\mathrm{NO}_{3}{ }^{-}$enriched water (Caffrey et al., 2003; Fernandes and LokaBharathi, 2011). In upwelled water off Trivandrum, a similar situation was encountered. Our data showed marked increase in NRA over nitrification (except at station no. 5 where nitrification was pre-dominant) with a maximum of $0.85( \pm 0.02) \mu \mathrm{mol} \mathrm{L}^{-1} \mathrm{~h}^{-1}$ recorded in the surficial nearshore waters (Fig. 6). This rate was $\sim 29 \mathrm{x}$ higher than the maximum rate recorded in the non-upwelled waters off Kochi. Fernandez and Farías (2012) have observed $\mathrm{NO}_{3}{ }^{-}$uptake rates that were 5 times higher during upwelling than the non-upwelling. The $\mathrm{NO}_{3}^{-}$reduction rates reported here are also far greater than those in the Peruvian, Costa Rican and Chilean upwelling system (Franck et al., 2005; Fernández et al., 2009; Fernandez and Farías, 2012) which never exceed $>0.1 \mu$ mol $\mathrm{L}^{-1} \mathrm{~h}^{-1}$. Nitrate reduction is generally mediated by facultative anaerobes. Under non-upwelling conditions, we anticipate NRA to be more pronounced in deeper waters where favourable conditions persist due to low-oxygen levels and substrate availability from the benthic environment. Interestingly, our study has shown NRA to pervade to the surface off Trivandrum (Fig. 6) as a result of upwelling. Earlier observation by LokaBharathi et al. (1988) have also shown that lithotrophic nitrate-reducers isolated from the nearshore and surface waters in the Arabian sea exhibit higher activity as compared to those from offshore or deeper waters. In oxygen-poor waters, nitrification can act as a crucial link between regenerated $\mathrm{N}$ and it's loss via denitrification/anammox. Though the oxidative phase of the $\mathrm{N}$ cycle was lower in occurrence than the reductive phase at Trivandrum, nitrification values reported in the present study are about an order higher than in other upwelling systems (Fernandez and Farías, 2012). At Kochi, nitrification activity was more pronounced towards the coast (Fig. 6). No major difference between nitrification and NRA activity was observed at Kochi implying efficient N cycling and the prevalence of homeostasis in the aquatic system.

As NRA prevailed over nitrification in upwelled waters, we used statistical tools to understand the influence of environmental variables on the process. Oxygen concentration (Davies et al., 1989), $\mathrm{NO}_{3}{ }^{-}$availability, concentrations of dissolved organic carbon content and nitrate reducing bacterial community (Koike and Sørensen, 1988; Bowles et al., 2012) have been cited as some of the variables governing $\mathrm{NO}_{3}{ }^{-}$removal rates in marine systems. Pearson's correlation analysis carried out in the present study revealed an inverse relationship between $\mathrm{NRA}$ and $\mathrm{NO}_{3}{ }^{-}$concentration (Fig. 7b) which is suggestive of more elevated rates of nutrient removal off Trivandrum than at Kochi. A decrease in NRA with depth was also observed at this location which strengthens our observation that NRA pervades the 
surface waters during upwelling. It also suggests enhancement of microbially-mediated $\mathrm{NO}_{3}{ }^{-}$uptake which could be stimulated by the presence of low oxygen-containing deeper waters in the euphotic zone. NRA therefore appears to be more dependent on $\mathrm{NO}_{3}{ }^{-}$drawn up the shelf during upwelling rather than its intrinsic production through nitrification.

In this study, PCA was used to understand the combined influence of environmental factors on NRA in the newly upwelled waters off Trivandrum. Variables like temperature, density, $\mathrm{pH}, \mathrm{NO}_{3}{ }^{-}, \mathrm{PO}_{4}{ }^{-}$ $\mathrm{SiO}_{2}$, Chl $a$, phaeopigments and phytoplankton abundance were strongly correlated to the first component highlighting their importance as primary indicators of upwelling. A clustering of nearshore locations (stations 1 \& 2) where high NRA, elevated $\mathrm{NH}_{4}^{+}$concentration, $\mathrm{BP}, \mathrm{Chl} a$ content and mesozooplankton abundance prevailed was observed (Fig. 8a and b). In nearshore locations, phytoplankton abundance was far lower as compared to the other sampling locations (Fig. 5) and could be attributed to the grazing activity of mesozooplankton (Landry et al., 2009). Studies carried out in an upwelling region off northern California (Slaughter et al., 2006) have also shown mesozooplankton grazing impact to be higher during weak upwelling than during periods of stronger upwelling. Unlike $\mathrm{NO}_{3}{ }^{-}$, no shoaling in isolines of $\mathrm{NH}_{4}{ }^{+}$was observed across the shelf off Trivandrum. A strong positive relationship between Chl $a$ and phaeopigments has been observed $(r=0.92, p<0.001$; Fig. 7a) in this study which is indicative of $\mathrm{NH}_{4}^{+}$production through re-mineralization of organic matter in the nearshore waters. In addition, excretion by mesozooplankton (Hernandez-Leon et al., 2008) could also be a key factor contributing to $\mathrm{NH}_{4}^{+}$generation off Trivandrum. Despite such observations, DNC values suggest that upwelling is still in the initial stages. In an upwelling area, NW of Spain, Varela et al. (2003) observed that inorganic nitrogen concentrations were mainly related to $\mathrm{NO}_{3}{ }^{-}$enrichment by upwelling pulses, while low ammonium concentrations were maintained by coupling between regeneration and uptake. In reduced environments, a strong coupling between nitrification and denitrification pathways has been suggested (Fernandes et al., 2012). In the coastal Arabian Sea, oxygen-deficient conditions support high productivity driven coupling between nitrification and denitrification (Krishnan et al., 2008). Ammonium is an important substrate for nitrification as it is oxidized to $\mathrm{NO}_{2}^{-}$during the first step of nitritation. However, at Trivandrum, nearshore $\mathrm{NO}_{3}{ }^{-}$ concentration at station $1 \& 2$ were $\sim 2 x$ higher than that of $\mathrm{NH}_{4}{ }^{+}$(Fig. 2). This would have caused a pronounced increase in denitrifying activity in order to modulate excess nutrient level (Fernandes et al., 2010; Fernandes and LokaBharathi, 2011) within the aquatic system. A low ratio (0.28) of nitrification over NRA (Table 3) in the nearshore locations off Trivandrum strengthens our inference on the 
possibility of a shift towards reduction in the $\mathrm{N}$ cycle even as early as the onset of monsoon. This ratio is higher than other nearshore reducing systems e.g. surficial mangrove sediments (Fernandes et al., 2012) where nitrification/NRA varies from $0.03-0.07$.

Bacteria displaying particular physiological properties (nitrifiers, nitrate reducers and even general heterotrophs) play a key role in maintaining homeostasis in aquatic ecosystems. Heterotrophic bacteria for example, contribute highly to organic matter decomposition and transformation. Their activities could be limited by the amount of substrate available (Murrell, 2003) e.g. the activity of denitrifiers is limited by the amount of $\mathrm{NO}_{3}{ }^{-}$available (Fernandes and LokaBharathi, 2011). In the present study, statistical analyses did not reveal any relationship between NRA and abundance of bacterial groups (Fig. 7a, Table S1) indicating that they do not limit the activity. It may be noted that interpretation of the patterns of PCA data are based on the first two components of the PCA since these components explained almost $46 \%$ the variation. This implies that there are other factors that are important in explaining the patterns seen but not included in the analysis. For example, nitrate reduction could be more dependent on the specific activity of the bacterial community capable of $\mathrm{NO}_{3}{ }^{-}$removal. In anoxic mangrove sediments, a similar observation has been made by Fernandes et al. (2012) wherein no correlation between denitrifier abundance and their activity was observed indicating that denitrification was more dependent on the specific activity of the denitrifying community.

Though our experiments were setup exclusively under microaerophilic and dark conditions to enable measurement of nitrate removal by bacteria, some uptake of the nutrient by phytoplankton cannot be completely ruled out. Phytoplankton blooms typically peak 4-6 days after initiation of upwelling (Wetz and Wheeler, 2004). When ambient concentrations of nitrate are significantly higher than those of ammonium, most of the nitrate uptake has been attributed to heterotrophic bacteria (Middelburg and Nieuwenhuize, 2000). A similar scenario could be occurring off Trivandrum which is characterized by higher bacterial productivity and nitrate concentrations in the nearshore region. Here, bacterial transformation of nitrate might be exceeding its uptake by phytoplankton during the initial stage of upwelling. Thus, bacteria could be playing important roles as moderating agents facilitating phytoplankton development (Carvalho and Gonzalez-Rodriguez, 2004) in freshly upwelled waters. 


\section{Conclusion}

Hydrographic measurements revealed the onset of upwelling off Trivandrum and it's absence off Kochi. Low DNC values off Trivandrum reflected the initial phase of the phenomenon. Besides, Trivandrum was marked by elevated NRA than nitrification. A decrease in NRA with depth was also observed strengthening our hypothesis that nutrient draw-up during upwelling causes the process to pervade surface waters. Consequently, the process is not restricted to the sub-surface re-iterating our earlier observations that the activity is strongly governed by the ambient $\mathrm{NO}_{3}{ }^{-}$concentration (Fernandes and LokaBharathi, 2011). Statistical analysis showed that intrinsic ammonification and nitrification have a minor role. The fall in level of $\mathrm{NO}_{3}{ }^{-}$in newly upwelled water at the surface can not only be attributed to uptake by phytoplankton but also to vigorous reduction by bacteria. These responses of bacteria underline their integral role in the maintenance of holistic systems. Such re-conditioning of upwelled water by microbial activity could be a pre-requisite for restoring the homeostasis and initiation of primary production that is eventually important for the tertiary trophic level.

\section{Acknowledgements}

We thank the Director, CSIR - National Institute of Oceanography, Goa (India) for the facilities. The authors acknowledge the support rendered by the Ministry of Earth Science and Director, CMLRE, Kochi, India for providing FORV Sagar Sampada. The authors are thankful to all participants of cruise no. 276, FORV Sagar Sampada for assisting in sample collection. This is NIO contribution no. XXXX.

\section{References}

Alexander, M., Clark, F.E., 1965. Nitrifying Bacteria. In: Black, C.A., Evans, D.D., White, J.L., Ensminger, L.E., Clark, F.E. (Eds.), Methods of Soil Analysis. Part 2. American Society of Agronomy, Madison, pp. 1477-1483.

Alvarez-Salgado, X.A., Roson, G., Perez, F.F., Figueiras, F.G., Pazos, Y., 1996. Nitrogen cycling in an estuarine upwelling system, the Ria de Arousa (NW Spain). Short-time-scale patterns of hydrodynamic and biogeochemical circulation. Mar. Ecol. Prog. Ser. 135, 259-273.

Antony, M.K., Unnikrishnan, A.S., 1992. On an upwelling front, propagation of upwelling and vertical velocity in the eastern Arabian sea during monsoon, 1987. Proceedings of Conference for Pacific Ocean Environments and Probing, Okinawa, Japan, 25-31 Aug 1992. PORSEC, Shimizu, Japan; $527-532$.

Bowles, M.W., Nigro, L.M., Teske, A.P., Joye, S.B., 2012. Denitrification and environmental factors influencing nitrate removal in Guaymas Basin hydrothermally altered sediments. Front. Microbiol. 3(377), 1-11. 
Caffrey, J.M., Harrington, N.E., Solem, I., Ward, B.B., 2003. Biogeochemical processes in a small California estuary. Nitrification activity, community structure and role in nitrogen budgets. Mar. Ecol. Prog. Ser. 248, 27-40.

Carvalho, W.F., Gonzalez-Rodriguez, E., 2004. Development of primary and bacterial production in upwelling waters of Arraial do Cabo region, RJ (Brazil). Braz. J. Oceanogr. 52, 35-45.

Cattell, R.B., 1966. The scree test for the number of factors. Multivar. Behav. Res. 1, 245-276.

Chen, C.T.A., Hsing, L.Y., Liu, C.L., Wang, S.L., 2004. Degree of nutrient consumption of upwelled water in the Taiwan Strait based on dissolved organic phosphorus or nitrogen. Mar. Chem. 87, $73-86$.

Chen, C.T.A., Wang, B.J., Hsing, L.Y., 2004. Upwelling and degree of nutrient consumption in Nanwan bay, southern Taiwan. J. Mar. Sci. Tech. 12(5), 442-447.

Couto de Brito, I.R., 2009. Ecology of nitrification in oil refinery wastewater treatment systems. PhD thesis, University of Newcastle upon Tyne, UK.

Davies, K.J., Lloyd, D., Boddy, L., 1989. The effect of oxygen on denitrification in Paracoccus denitrificans and Pseudomonas aeruginosa. J. Gen. Microbiol. 135(9), 2445-2451.

Dufour, P., Charpy, L., Bonnet, S., Garcia, N., 1999. Phytoplankton nutrient control in the oligotrophic South Pacific subtropical gyre. Mar. Ecol. Prog. Ser. 179, 285-290.

Fernandes, S.O., LokaBharathi, P.A., 2011. Nitrate levels modulate denitrification activity in tropical mangrove sediments (Goa, India). Environ. Monit. Assess. 173(1-4), 117-125.

Fernandes, S.O., Bonin, P.C., Michotey, V.D., LokaBharathi, P.A., 2010. Denitrification: An important pathway for nitrous oxide production in tropical mangrove sediments (Goa, India). J. Environ. Qual. 39(4), 1507-1516.

Fernandes, S.O., Bonin, P.C., Michotey, V.D., Garcia, N., LokaBharathi, P.A., (2012) Nitrogen-limited mangrove ecosystems conserve $\mathrm{N}$ through dissimilatory nitrate reduction to ammonium. Sci. Rep. 2, 419, doi:10.1038/srep00419.

Fernandes, S.O., Gonsalves, M.J., Michotey, V.D., Bonin, P.C., LokaBharathi, P.A., 2013. Denitrification activity is closely linked to the total ambient Fe concentration in mangrove sediments of Goa, India. Estuar. Coast. Shelf S. 131, 64-74.

Fernandes, S.O., Michotey, V.D., Guasco, S., Bonin, P.C., LokaBharathi, P.A., 2012. Denitrification prevails over anammox in tropical mangrove sediments (Goa, India). Mar. Environ. Res. 74, 9 19.

Fernandez, C., Farías, L., 2012. Assimilation and regeneration of inorganic nitrogen in a coastal upwelling system: ammonium and nitrate utilization. Mar. Ecol. Prog. Ser. 451, 1-14.

Fernández, C., Farias, L., Alcamán, M., 2009. Primary production and nitrogen regeneration processes in surface waters of the Peruvian upwelling system. Prog. Oceanogr. 83, 159-168. 
Franck, V.M., Smith, G., Bruland, K., Brzezinski, M.A., 2005. Comparison of size-dependent carbon, nitrate, and silicic acid uptake rates in high- and low-iron waters. Limnol. Oceanogr. 50, $825-838$.

Gabriel, K.R., 1971. The biplot graphic display of matrices with application to principal component analysis. Biometrika 58, 453-467.

Gilbert, F., Philippe, S., Bianchi, M., Bonin, P., 1997. Influence of shellfish farming activities on nitrification, nitrate reduction to ammonium and denitrification at the water-sediment interface of the Thau lagoon, France. Mar. Ecol. Prog. Ser. 151, 143-153.

Ginestet, P., Audic, J.M., Urbain, V., Block, J.C., 1998. Estimation of nitrifying bacterial activities by measuring oxygen uptake in the presence of the metabolic inhibitors allylthiourea and azide. Appl. Environ. Microbiol. 64(6), 2266-2268.

Habeebrehman, H., Prabhakaran, M.P., Jacob, J., Sabu, P., Jayalakshmi, K.J., Achuthankutty, C.T., Revichandran, C., 2008. Variability in biological responses influenced by upwelling events in the Eastern Arabian Sea. J. Mar. Sys. 74(1-2), 545-560.

Hernandez-Leon, S., Fraga, C., Ikeda, T., 2008. A global estimation of mesozooplankton ammonium excretion in the open ocean. J. Plankton Res. 30(5), 577-585.

Hobbie, J.E., Daley, R.J., Jasper, S., 1977. Use of nucleopore filters for counting bacteria by fluorescence microscopy. Appl. Environ. Microbiol. 33, 1225-1228.

Jyothibabu, R., AshaDevi, C.R., Madhu, N.V., Sabu, P., Jayalakshmy, K.V., Jacob, J., Habeebrehman, H., Prabhakaran, M.P., Balasubramanian, T., Nair, K.K.C., 2008. The response of microzooplankton $(20-200 \mu \mathrm{m})$ to coastal upwelling and summer stratification in the southeastern Arabian Sea. Cont. Shelf Res. 28(4-5), 653-671.

Kogure, K., Simidu, U., Taga, N., 1984. An improved direct viable count method for aquatic bacteria. Arch. Hydrobiol. 102, 117-122.

Koike, I., Sørensen, J., 1988. Nitrate reduction and denitrification in marine sediments. In: Blackburn, T.H., Sørensen, J. (Eds.), Nitrogen cycling in coastal marine environments. John Wiley \& Sons, Chichester, pp. 251-273.

Krishna, K.M., 2008. Coastal upwelling along the southwest coast of India - ENSO modulation. Ocean Sci. Discuss. 5, 123-134.

Krishnan, K.P., Fernandes, S.O., LokaBharathi, P.A., Krishna Kumari, L., Nair, S., Pratihary, A.K., Ramalingeswara Rao, B., 2008. Anoxia over the western continental shelf of India: Bacterial indications of intrinsic nitrification feeding denitrification. Mar. Environ. Res. 65, 445-455.

Kuypers, M.M.M., Lavik, G., Woebken, D., Schmid, M., Fuchs, B.M., Amann, R., Jørgensen, B.B., Jetten, M.S.M., 2005. Massive nitrogen loss from the Benguela upwelling system through anaerobic ammonium oxidation. Proc. Natl. Acad. Sci. USA 102(18), 6478-6483.

Landry, M.R., Ohman, M.D., Goericke, R., Stukel, M.R., Tsyrklevich, K., 2009. Lagrangian studies of phytoplankton growth and grazing relationships in a coastal upwelling ecosystem off Southern California. Prog. Oceanogr. 83, 208-216. 
Lathipha, P.N., Murthy, A.V.S., 1985. Studies of Upwelling along the west coast of India using geopotential Anomaly. Indian J. Mar. Sci. 14, 10-14.

LokaBharathi, P.A., Chandramohan, D., Nair, S. 1988. A preliminary study of anaerobic thiosulfateoxidising bacteria as denitrifiers in the Arabian Sea. Geomicrobiol. J. 6, 195-207.

LokaBharathi, P.A., Nair, S., Chandramohan, D., 1992. Nitrate and sulfate reducers-retrievable number of bacteria and their activities in Indian waters. In: Desai, B.N. (Ed.), Oceanography of the Indian Ocean, Oxford \& IBH, pp. 47-55.

LokaBharathi, P.A., Nair, S., DeSouza, M.J.B.D., Chandramohan, D., 1999. Truce with oxygen Anaerobiosis outcompete aerobiosis in the Antarctic lacustrine bacteria Curr. Sci. 76(12), 15851587.

Madhupratap, M., Nair, S.R.S., Haridas, P., Padmavati, G., 1990. Response of zooplankton to physical changes in the environment: coastal upwelling along central west coast of India. J. Coastal Res. $6,413-426$.

Maheswaran, M., 2000. Upwelling along the southwest coast of India. Indian J. Mar. Sci. 15, 20-24.

Michotey, V.D., Méjean, V., Bonin, P.C., 2000. Comparison of methods for quantification of cytochrome $c d_{1}$-denitrifying bacteria in environmental marine samples. Appl. Environ. Microbiol. 66, 1564-1571.

Middelburg, J.J., Nieuwenhuize, J., 2000. Nitrogen uptake by heterotrophic bacteria and phytoplankton in the nitrate-rich Thames estuary. Mar. Ecol. Prog. Ser. 203, 13-21.

Muraleedharan, P.M., PrasannaKumar, S., 1996. Arabian Sea upwelling - A comparison between coastal and open ocean regions. Curr. Sci. 71(11), 842-846.

Murrell, M.C., 2003. Bacterioplankton dynamics in a subtropical estuary: evidence for substrate limitation. Aquat. Microb. Ecol. 32, 239-250.

Ramaiah, N., Raghukumar, S., Gauns, M., 1996. Bacterial abundance and production in the central and eastern Arabian Sea. Curr. Sci. 71(11), 878-882.

Rodina, A.G., 1972. Methods in aquatic microbiology, University Park Press, Butterworths, Baltimore London pp. 269-291.

Rodriguez, E.G., Valentine, J.L., Andre, D.L., Jacob, S.A., 1992. Upwelling and down welling at Cabo Frio (Brazil). Comparison of biomass and production responses. J. Plankton Res. 14(2), 289306.

Roegner, G.C., Needoba, J.A., Baptista, A.M., 2011. Coastal upwelling supplies oxygen-depleted water to the Columbia river estuary. PLoS One 6(4), e18672. doi:10.1371/journal.pone.0018672

Sawant, S., Madhupratap, M., 1996. Seasonality and composition of phytoplankton in the Arabian Sea. Curr. Sci. 71, 869-873.

Schott, F.A., McCreary, J.P., 2001. The monsoon circulation of the Indian Ocean. Prog. Oceanogr. 51, $1-123$. 
Simu, K., Holmfeldt, K., Zweifel, U. L., Hagström, Å., 2005. Culturability and coexistence of colonyforming and single-cell marine bacterioplankton. Applied Appl. Environ. Microbiol. 71(8), 4793-4800.

Slaughter, A.M., Bollens, S.M., Bollens, G.R., 2006. Grazing impact of mesozooplankton in an upwelling region off northern California, 2000-2003. Deep Sea Res. Part 2 Top. Stud. Oceanogr. 53(25-26), 3099-3115.

Smith, D.C., Azam, F., 1992. A simple, economical method for measuring bacterial protein synthesis rates in seawater using ${ }^{3} \mathrm{H}$-leucine. Mar. Microb. Food Webs 6(2), 107-114.

Smith, S.L., Codispoti, L.A., 1980. Southwest monsoon of 1979: chemical and biological response of Somali coastal waters. Science 209(4456), 597-600.

Smitha, B.R., 2010. Coastal Upwelling of the South Eastern Arabian Sea - An integrated approach. PhD thesis, Cochin University of Science and Technology.

Sohm, J.A., Hilton, J.A., Noble, A.E., Zehr, J.P., Saito, M.A., Webb, E.A., 2011. Nitrogen fixation in the South Atlantic Gyre and the Benguela Upwelling System. Geophys. Res. Lett. 38, L16608.

Subina, N.S., Bhosle, S., Nair, S., LokaBharathi, P.A., 2012. Monsoonal variability in abiotic parameters in coastal waters off Trivandrum evokes press and pulse response in biotic variables. J. Coast. Environ. 3(1), 29-39.

Takahashi, M., Ishizaka, J., Ishimaru, T., Atkinson, L.P., Lee, T.N., Yamaguchi, Y., Fujita, Y., Ichimura, S., 1986. Temporal change in nutrient concentrations and phytoplankton biomass in short time scale local upwelling around the Izu Peninsula, Japan. J. Plankton Res. 8, 1039-1049.

UNESCO, 1994. Protocols for the Joint Global Ocean Flux Study (JGOFS) Core Measurements. Manual and Guide No 29, 179.

Varela, M.M., Barquero, S., Bode, A., Fernández, E., González, N., Teira, E., Varela, M., 2003. Microplanktonic regeneration of ammonium and dissolved organic nitrogen in the upwelling area of the NW of Spain: relationships with dissolved organic carbon production and phytoplankton size-structure. J. Plankton Res. 25 (7), 719-736.

Wetz, M.S., Wheeler, P.A., 2004. Response of bacteria to simulated upwelling phytoplankton blooms. Mar. Ecol. Prog. Ser. 272, 49-57.

Winkler, L.W., 1888. Die Bestimmung des in Wasser gelösten Sauerstoffen. Berichte der Deutschen Chemischen Gesellschaft. 21, 2843-2855.

Wurl, O., 2009. Practical guidelines for the analysis of seawater. CRC Press, Boca Raton. pp.143-178. 


\section{Legend to figures}

Fig. 1. Location of sampling sites off Trivandrum and Kochi.

Fig. 2. Hydrographic distribution of physico-chemical parameters viz., temperature (a), density (b), salinity (c), pH (d), dissolved oxygen (e) and nutrients (f-j) in the coastal waters off Trivandrum.

Fig. 3. Hydrographic distribution of physical (a-d) and chemical parameters (e-j) off Kochi.

Fig. 4. Vertical distribution of Chl $a$ and phaeopigments off Trivandrum and Kochi.

Fig. 5. Phytoplankton and mesozooplankton abundance off Trivandrum and Kochi.

Fig. 6. Nitrification and nitrate reducing activity off Trivandrum and Kochi. Note change in scale for plots at station $1 \& 2$.

Fig. 7. A network visualization of mathematical interactions (correlations) depicting the complexity between various abiotic/biotic components in an upwelling system (a). These correlations (Pearson's correlation analysis, $n=34$ ) are significant at $0.05,0.01$ and 0.001 probability level. The $r$ values have been denoted at the connectors between nodes. Within this web of interactions, NRA which has significant relationship with variables like nitrate concentration, density, salinity, etc. has been expanded (b). Factors influencing nitrate reducing activity have been arranged based on the hierarchy of $r$ values denoted at the connector of each node. Variables Temp, temperature; DO, dissolved oxygen; Chl $a$, chlorophyll $a$; BP, bacterial productivity; TVC_a, total aerobic viable cells; NRB, nitrate reducing bacteria; NRA, nitrate reducing activity; Mesozoo. abund, mesozooplankton abundance; Phyto. abund, phytoplankton abundance.

Fig. 8. Principal component analysis (PCA) plots (first and second components) of environmental variables and bacterial activities (a) and sampling points (b) off Trivandrum. Variables Temp, temperature; DO, dissolved oxygen; Chl $a$, chlorophyll $a$; BP, bacterial productivity; TC, total bacterial cells; TVC_a, total aerobic viable cells; TVC_an, total anaerobic viable cells; THB, total heterotrophic bacteria; NRB, nitrate reducing bacteria; NRA, nitrate reducing activity. In the plot, the eigenvectors (projected parameters) point in the direction of maximum variation and the length of each parameter is equivalent to their rate of change in the dataset. Eigenvectors in opposite directions imply negative correlations while those in the same direction are positively correlated. Oblique angles between two vectors imply in a certain degree of relatedness between vectors whereas right angles between vectors show they are independent from one another (Couto de Brito 2009). 


\section{Table 1}

Bacterial productivity, abundance of various physiological groups and degree of nutrient consumption (DNC) off Trivandrum.

\begin{tabular}{|c|c|c|c|c|c|c|c|c|c|}
\hline $\begin{array}{c}\text { Station } \\
\text { no. }\end{array}$ & $\begin{array}{l}\text { Depth } \\
\text { (m) }\end{array}$ & $\begin{array}{l}\text { BP } \\
\left(\text { pmol L-1 } h^{-1}\right)\end{array}$ & $\begin{array}{l}\mathrm{TC} \\
\left(\mathrm{x} 10^{9}\right. \\
\left.\text { cells L } \mathrm{L}^{-1}\right)\end{array}$ & $\begin{array}{l}\text { TVC_a } \\
\left(x 10^{8}-\right. \\
\left.\text { cells L }{ }^{-1}\right)\end{array}$ & $\begin{array}{l}\text { TVC an } \\
\left(\mathrm{x} 10^{7} \text { cells }\right. \\
\left.\mathrm{L}^{-1}\right)\end{array}$ & $\begin{array}{l}\text { THB } \\
\left(\mathrm{x} 10^{7} \mathrm{CFU}\right. \\
\left.\mathrm{L}^{-1}\right)\end{array}$ & $\begin{array}{l}\text { Nitrifiers } \\
\left(\mathrm{x} 10^{9} \mathrm{MPN}\right. \\
\left.\text { cells L }{ }^{-1}\right)\end{array}$ & $\begin{array}{l}\text { NRB } \\
\left(\mathrm{x} \mathrm{10} 0^{9}\right. \\
\text { MPN } \\
\text { cells L-1) }\end{array}$ & DNC \\
\hline \multirow[t]{6}{*}{1} & \multirow[t]{2}{*}{5} & \multirow[t]{2}{*}{$32.00 \pm 0.94$} & $\begin{array}{l}1.30 \pm \\
0.73\end{array}$ & $\begin{array}{l}6.18 \pm \\
2.57\end{array}$ & $\begin{array}{l}0.53 \pm \\
0.06\end{array}$ & $\begin{array}{l}9.00 \pm \\
3.56\end{array}$ & \multirow[t]{2}{*}{1.40} & \multirow[t]{2}{*}{11.00} & \multirow[t]{2}{*}{0.12} \\
\hline & & & $0.93 \pm$ & $6.81 \pm$ & $1.24 \pm$ & $2.00 \pm$ & & & \\
\hline & \multirow[t]{2}{*}{15} & \multirow[t]{2}{*}{$1.66 \pm 0.05$} & 0.52 & 4.65 & 1.02 & 1.33 & \multirow[t]{2}{*}{1.40} & \multirow[t]{2}{*}{0.35} & \multirow[t]{2}{*}{0.08} \\
\hline & & & $0.76 \pm$ & $6.34 \pm$ & $0.71 \pm$ & $0.90 \pm$ & & & \\
\hline & \multirow[t]{2}{*}{25} & \multirow[t]{2}{*}{$1.37 \pm 0.04$} & 0.43 & 5.05 & 0.24 & 0.14 & \multirow[t]{2}{*}{1.40} & \multirow[t]{2}{*}{0.00} & \multirow[t]{2}{*}{0.01} \\
\hline & & & $0.78 \pm$ & $4.43 \pm$ & $0.18 \pm$ & $0.90 \pm$ & & & \\
\hline \multirow[t]{8}{*}{2} & \multirow{2}{*}{5} & \multirow{2}{*}{$2.80 \pm 0.08$} & 0.44 & 7.08 & 0.04 & 0.13 & \multirow[t]{2}{*}{1.40} & \multirow{2}{*}{0.11} & 0.04 \\
\hline & & & $0.86 \pm$ & $4.94 \pm$ & $0.18 \pm$ & $0.40 \pm$ & & & \\
\hline & 15 & $2.85 \pm 0.08$ & 0.48 & 3.14 & 0.08 & 0.24 & 1.40 & 11.00 & 0.02 \\
\hline & & & $0.89 \pm$ & $4.71 \pm$ & $0.35 \pm$ & $1.20 \pm$ & & & \\
\hline & 25 & $1.48 \pm 0.04$ & 0.50 & 3.67 & 0.13 & 0.09 & 1.40 & 0.75 & 0.01 \\
\hline & & & $0.81 \pm$ & $2.05 \pm$ & $0.89 \pm$ & $0.70 \pm$ & & & \\
\hline & 45 & $5.00 \pm 0.15$ & 0.45 & 1.55 & 0.16 & 0.17 & 1.40 & 0.30 & 0.01 \\
\hline & & & $0.67 \pm$ & $4.60 \pm$ & $1.24 \pm$ & $3.40 \pm$ & & & \\
\hline 3 & 5 & $0.14 \pm 0.01$ & 0.38 & 2.39 & 0.38 & 2.31 & 1.40 & 4.50 & 0.53 \\
\hline & & & $1.09 \pm$ & $5.06 \pm$ & $2.83 \pm$ & $1.60 \pm$ & & & \\
\hline & 25 & $0.69 \pm 0.02$ & 0.61 & 4.91 & 0.62 & 0.84 & 1.40 & 0.01 & 0.01 \\
\hline & & & $0.68 \pm$ & $5.06 \pm$ & $1.95 \pm$ & $1.90 \pm$ & & & \\
\hline & 50 & $1.20 \pm 0.04$ & 0.38 & 3.81 & 0.37 & 1.30 & 1.40 & 0.20 & 0.01 \\
\hline & & & $0.74 \pm$ & $3.26 \pm$ & $3.89 \pm$ & $0.00 \pm$ & & & \\
\hline & 75 & $2.60 \pm 0.08$ & 0.41 & 1.49 & 1.61 & 0.00 & 1.40 & 2.00 & 0.01 \\
\hline & & & $1.26 \pm$ & $4.34 \pm$ & $4.96 \pm$ & $1.30 \pm$ & & & \\
\hline & 100 & $5.20 \pm 0.15$ & 0.70 & 2.43 & 1.94 & 0.11 & 1.40 & 0.30 & 0.01 \\
\hline & & & $0.93 \pm$ & $2.42 \pm$ & $0.53 \pm$ & $2.40 \pm$ & & & \\
\hline 4 & 5 & $4.67 \pm 0.14$ & 0.52 & 1.14 & 0.10 & 0.15 & 1.40 & 0.30 & 0.55 \\
\hline & & & $1.55 \pm$ & $1.29 \pm$ & $0.89 \pm$ & $0.40 \pm$ & & & \\
\hline & 25 & $4.63 \pm 0.08$ & 0.87 & 0.65 & 0.06 & 0.36 & 1.40 & 0.30 & 0.57 \\
\hline & & & $1.04 \pm$ & $2.46 \pm$ & $0.71 \pm$ & $2.40 \pm$ & & & \\
\hline & 50 & $5.46 \pm 0.16$ & 0.58 & 1.60 & 0.34 & 0.86 & 0.04 & 0.15 & 0.01 \\
\hline & & & $0.92 \pm$ & $3.93 \pm$ & $0.71 \pm$ & $6.30 \pm$ & & & \\
\hline & 75 & $5.97 \pm 0.18$ & 0.52 & 1.53 & 0.21 & 0.35 & 0.01 & 0.11 & 0.00 \\
\hline & & & $0.95 \pm$ & $5.08 \pm$ & $1.95 \pm$ & $0.80 \pm$ & & & \\
\hline & 150 & $4.03 \pm 0.12$ & 0.53 & 2.61 & 0.32 & 0.55 & 1.40 & 0.30 & 0.00 \\
\hline & & & $14.87 \pm$ & $5.70 \pm$ & $0.18 \pm$ & $1.20 \pm$ & & & \\
\hline & 200 & $2.78 \pm 0.08$ & 8.33 & 2.24 & 0.09 & 0.82 & 1.40 & 0.30 & 0.00 \\
\hline & & & $2.14 \pm$ & $5.01 \pm$ & $0.53 \pm$ & $0.80 \pm$ & & & \\
\hline 5 & 5 & $4.01 \pm 0.12$ & 1.20 & 2.96 & 0.15 & 0.47 & 1.10 & 0.35 & 0.24 \\
\hline & & & $2.41 \pm$ & $1.29 \pm$ & $7.08 \pm$ & $0.60 \pm$ & & & \\
\hline & 25 & $2.44 \pm 0.07$ & 1.35 & 0.65 & 3.73 & 0.21 & 1.40 & 0.11 & 0.20 \\
\hline & & & $1.66 \pm$ & $4.25 \pm$ & $0.89 \pm$ & $1.10 \pm$ & & & \\
\hline & 50 & $4.10 \pm 0.12$ & 0.93 & 1.27 & 0.09 & 0.32 & 0.30 & 140.00 & 0.01 \\
\hline & & & $1.49 \pm$ & $2.35 \pm$ & $0.53 \pm$ & $1.10 \pm$ & & & \\
\hline & 75 & $0.70 \pm 0.02$ & 0.84 & 0.46 & 0.03 & 0.17 & 1.40 & 0.11 & 0.01 \\
\hline & & & $1.15 \pm$ & $0.37 \pm$ & $0.00 \pm$ & $1.20 \pm$ & & & \\
\hline & 150 & $0.05 \pm 0.01$ & 0.64 & 0.07 & 0.00 & 0.18 & 1.40 & 0.20 & 0.00 \\
\hline
\end{tabular}




\begin{tabular}{|c|c|c|c|c|c|c|c|c|}
\hline \multirow[t]{2}{*}{250} & $0.12 \pm 0.01$ & $\begin{array}{l}1.12 \pm \\
0.62\end{array}$ & $\begin{array}{l}1.12 \pm \\
0.65\end{array}$ & $\begin{array}{l}1.06 \pm \\
0.06\end{array}$ & $\begin{array}{l}0.70 \pm \\
0.07\end{array}$ & \multirow[t]{2}{*}{1.40} & \multirow[t]{2}{*}{0.20} & \multirow[t]{2}{*}{0.00} \\
\hline & & $1.52 \pm$ & $0.12 \pm$ & $3.36 \pm$ & $1.40 \pm$ & & & \\
\hline \multirow{2}{*}{420} & $1.97 \pm 0.06$ & 0.85 & 0.03 & 1.26 & 0.40 & 0.04 & 0.20 & 0.00 \\
\hline & & $1.36 \pm$ & $2.81 \pm$ & $1.06 \pm$ & $0.00 \pm$ & & & \\
\hline \multirow[t]{2}{*}{5} & $2.94 \pm 0.09$ & 0.73 & 0.49 & 0.66 & 0.00 & 1.40 & 0.20 & 0.23 \\
\hline & & $1.37 \pm$ & $0.48 \pm$ & $1.06 \pm$ & $0.60 \pm$ & & & \\
\hline \multirow[t]{2}{*}{25} & $10.00 \pm 0.29$ & 0.77 & 0.37 & 0.06 & 0.18 & 1.40 & 4.50 & 0.24 \\
\hline & & $1.33 \pm$ & $1.95 \pm$ & $1.59 \pm$ & $0.40 \pm$ & & & \\
\hline \multirow[t]{2}{*}{50} & $1.13 \pm 0.03$ & 0.74 & 0.77 & 0.90 & 0.16 & 0.16 & 0.35 & 0.01 \\
\hline & & $1.48 \pm$ & $3.03 \pm$ & $1.95 \pm$ & $0.90 \pm$ & & & \\
\hline \multirow[t]{2}{*}{75} & $0.24 \pm 0.01$ & 0.73 & 0.56 & 0.66 & 0.19 & 1.40 & 140.00 & 0.00 \\
\hline & & $1.69 \pm$ & $3.17 \pm$ & $2.12 \pm$ & $2.00 \pm$ & & & \\
\hline \multirow[t]{2}{*}{150} & $0.94 \pm 0.03$ & 0.93 & 1.21 & 0.83 & 0.45 & 1.40 & 0.30 & 0.00 \\
\hline & & $1.35 \pm$ & $3.47 \pm$ & $1.59 \pm$ & $0.00 \pm$ & & & \\
\hline \multirow[t]{2}{*}{250} & $0.09 \pm 0.02$ & 0.76 & 1.20 & 0.20 & 0.63 & 1.40 & 0.35 & 0.00 \\
\hline & & $0.76 \pm$ & $3.38 \pm$ & $5.31 \pm$ & $1.00 \pm$ & & & \\
\hline \multirow[t]{2}{*}{500} & $1.84 \pm 0.05$ & 0.33 & 2.38 & 1.48 & 0.22 & 1.40 & 0.07 & 0.00 \\
\hline & & $0.89 \pm$ & $2.19 \pm$ & $7.61 \pm$ & $1.40 \pm$ & & & \\
\hline \multirow[t]{2}{*}{750} & $0.07 \pm 0.01$ & 0.53 & 2.25 & 2.89 & 2.43 & 1.40 & 0.30 & 0.00 \\
\hline & & $1.13 \pm$ & $2.00 \pm$ & $3.72 \pm$ & $1.80 \pm$ & & & \\
\hline 950 & $1.20 \pm 0.04$ & 0.63 & 1.49 & 0.97 & 1.15 & 1.40 & 0.11 & 0.12 \\
\hline
\end{tabular}

Note: BP, bacterial productivity; TC, total bacterial cells, TC_a, total aerobic viable cells; TC_an, total anaerobic viable cells; THB, total heterotrophic bacteria; NRB, nitrate reducing bacteria. At some sampling points, when MPN for nitrifiers and NRB are in excess of TC, they could at best be considered equal to TC. Use of liquid medium and longer incubation sometimes yield such higher MPN. 


\section{Table 2}

Bacterial productivity and abundance of various physiological groups off Kochi.

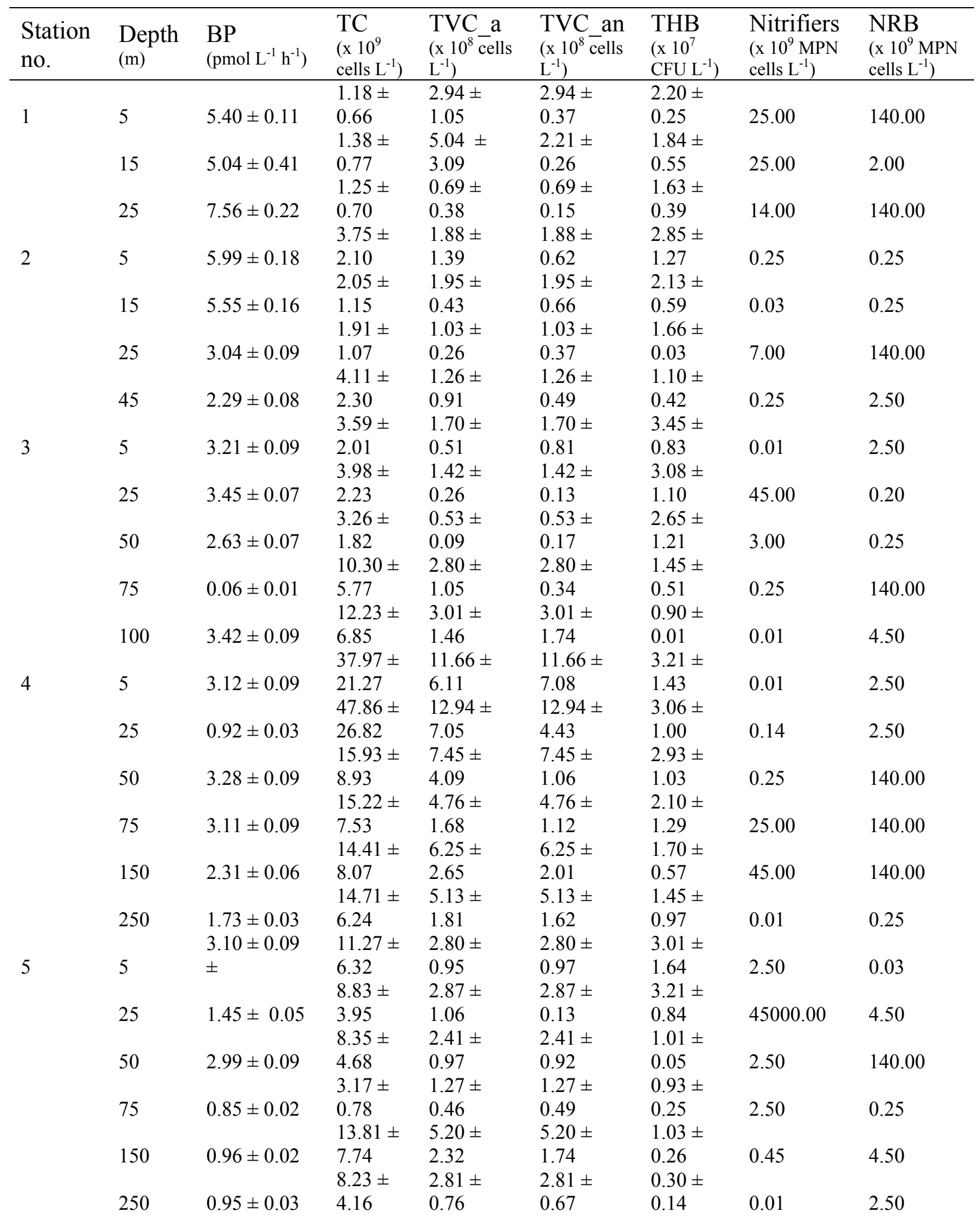




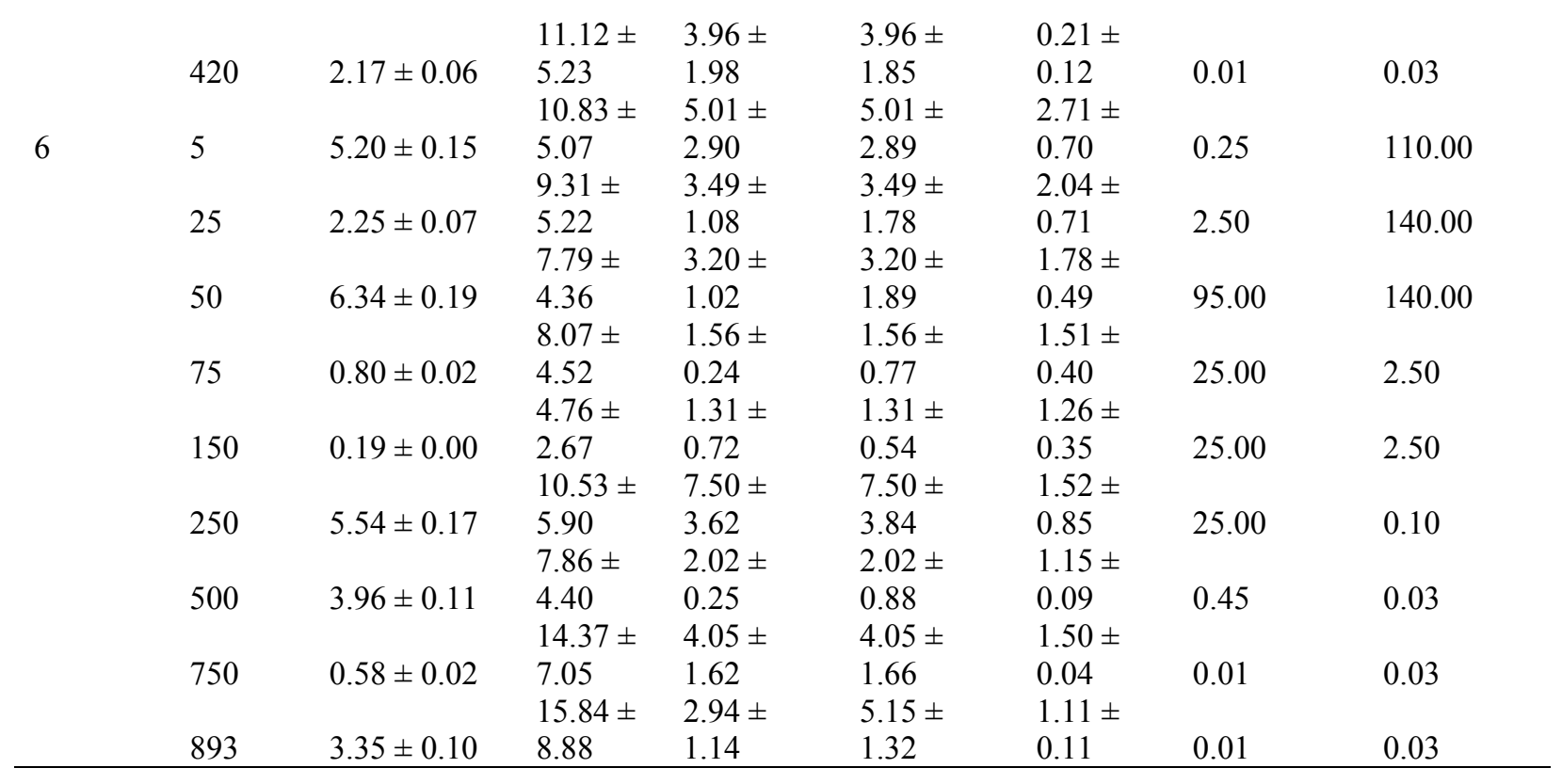




\section{Table 3}

Nitrification and NRA ratio in the nearshore stations off Trivandrum and Kochi.

\begin{tabular}{|c|c|c|c|c|c|}
\hline & $\underset{(\mathrm{m})}{\text { Depth }}$ & $\begin{array}{l}\text { Nitrification } \\
\left(\mu \mathrm{mol} \mathrm{L}^{-1} \mathrm{~h}^{-1}\right)\end{array}$ & $\underset{\left(\mu \mathrm{mol} \mathrm{L}^{-1} \mathrm{~h}^{-1}\right)}{\mathrm{NRA}}$ & $\begin{array}{c}\text { Ratio } \\
\text { (Nitrification/NRA) }\end{array}$ & $\begin{array}{c}\text { Average ratio } \\
\text { (Nitrification/NRA) }\end{array}$ \\
\hline \multicolumn{6}{|c|}{ Trivandrum } \\
\hline \multirow[t]{3}{*}{ Station 1} & 5 & $0.04( \pm 0.01)$ & $0.85( \pm 0.02)$ & 0.05 & \multirow{7}{*}{0.28} \\
\hline & 15 & $0.03( \pm 0.04)$ & $0.76( \pm 0.10)$ & 0.04 & \\
\hline & 25 & $0.02( \pm 0.00)$ & $0.66( \pm 0.08)$ & 0.03 & \\
\hline \multirow[t]{4}{*}{ Station 2} & 5 & $0.06( \pm 0.03)$ & $0.40( \pm 0.05)$ & 0.16 & \\
\hline & 15 & $0.09( \pm 0.04)$ & $0.36( \pm 0.13)$ & 0.26 & \\
\hline & 25 & $0.10( \pm 0.04)$ & $0.07( \pm 0.06)$ & 1.41 & \\
\hline & 45 & $0.00( \pm 0.00)$ & $0.07( \pm 0.04)$ & 0.00 & \\
\hline \multicolumn{6}{|l|}{ Kochi } \\
\hline \multirow[t]{3}{*}{ Station 1} & 5 & $0.10( \pm 0.04)$ & $0.40( \pm 0.30)$ & 0.25 & \multirow{7}{*}{2.35} \\
\hline & 15 & $0.14( \pm 0.02)$ & $1.61( \pm 0.03)$ & 0.09 & \\
\hline & 25 & $0.19( \pm 0.00)$ & $0.32( \pm 0.05)$ & 0.61 & \\
\hline \multirow[t]{4}{*}{ Station 2} & 5 & $0.20( \pm 0.02)$ & $0.33( \pm 0.23)$ & 0.60 & \\
\hline & 15 & $1.56( \pm 0.43)$ & $0.18( \pm 0.09)$ & 8.44 & \\
\hline & 25 & $0.34( \pm 0.08)$ & $3.24( \pm 0.05)$ & 0.10 & \\
\hline & 45 & $3.49( \pm 1.86)$ & $0.55( \pm 0.10)$ & 6.34 & \\
\hline
\end{tabular}




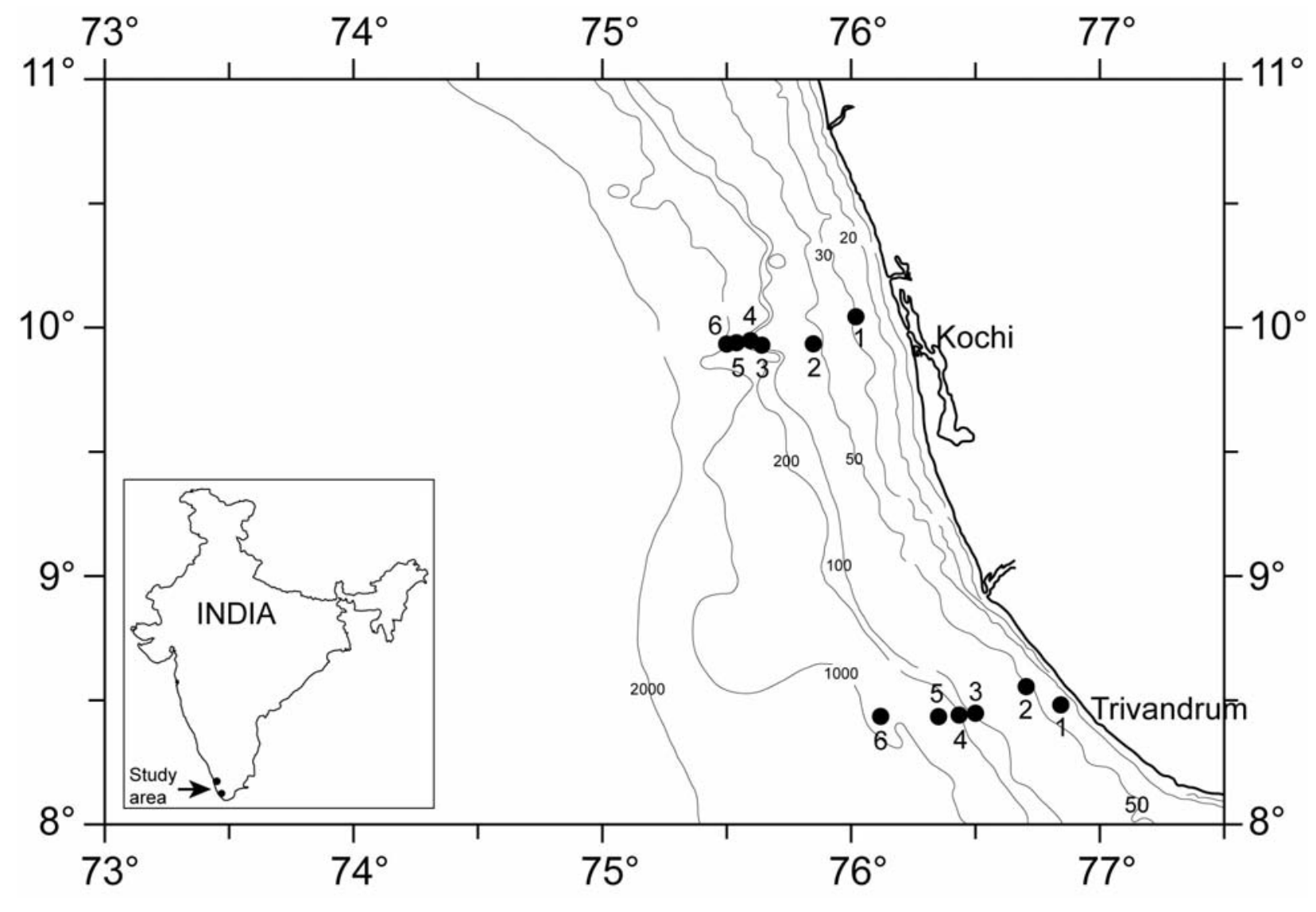

Fig. 1 


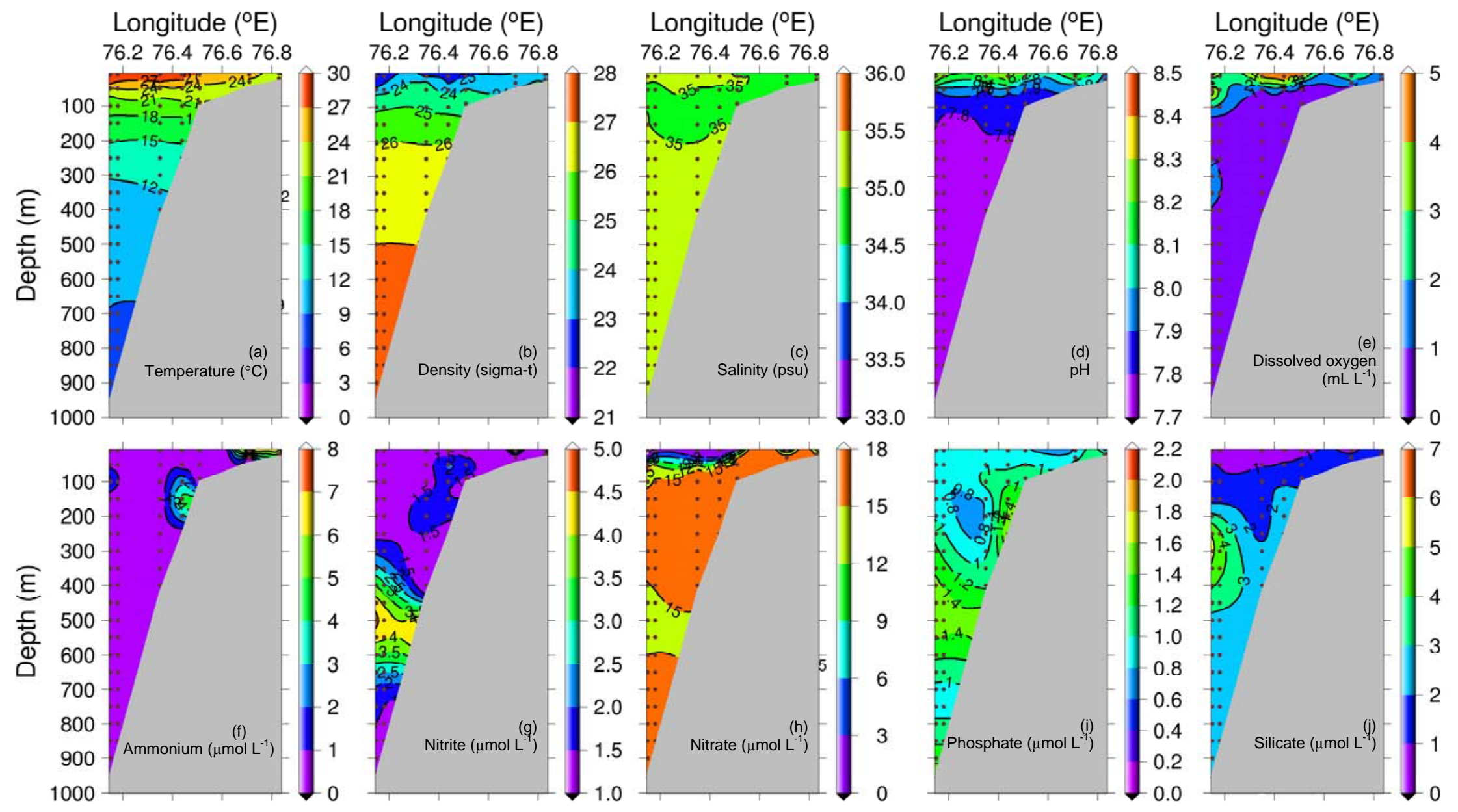

Fig. 2 


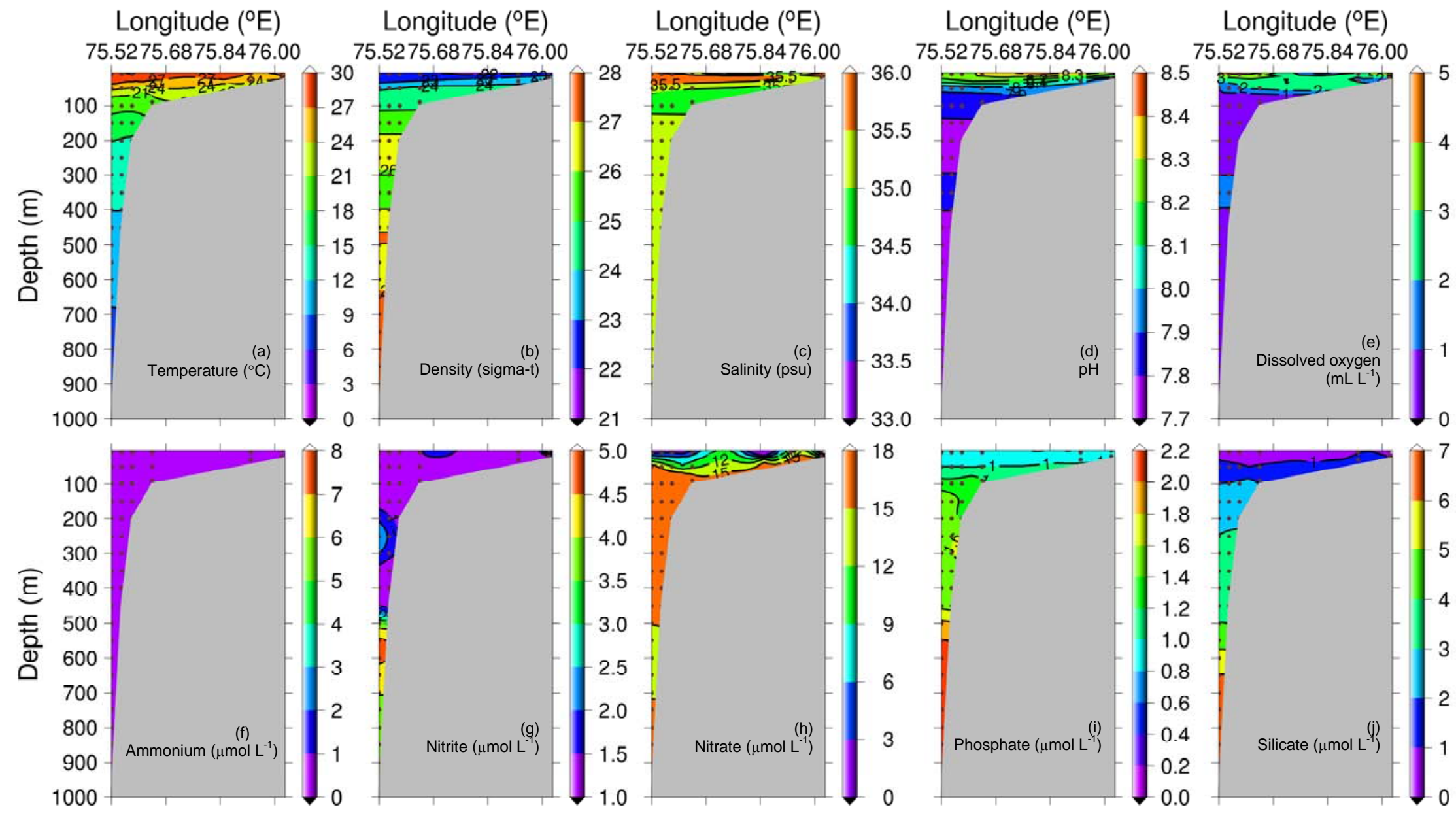

Fig. 3 


\section{Trivandrum}
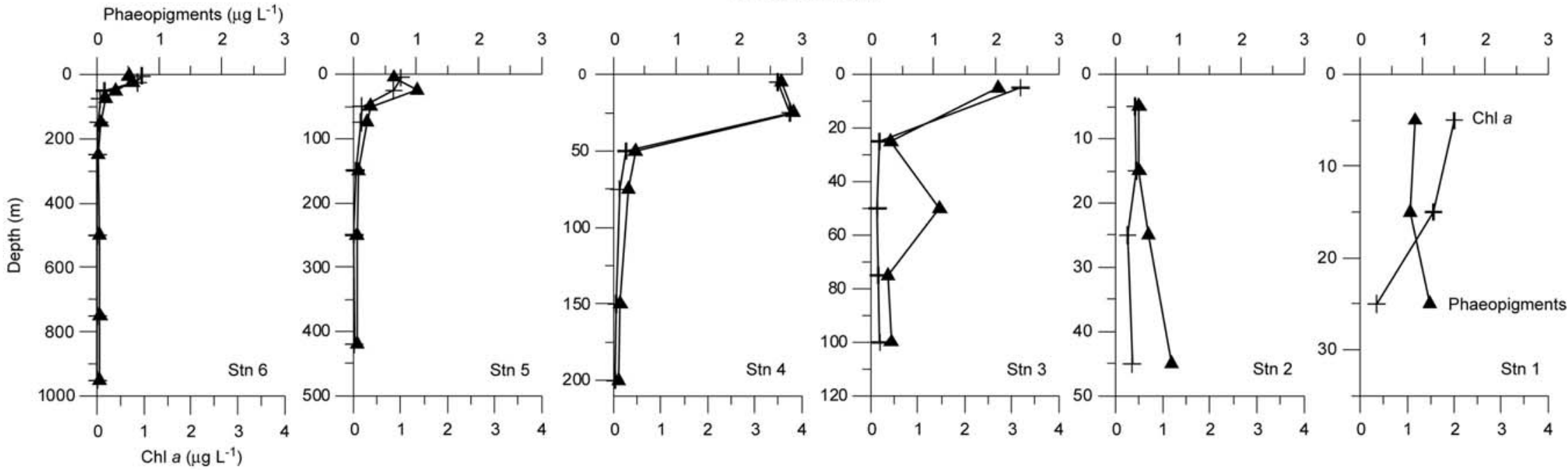

\section{Kochi}
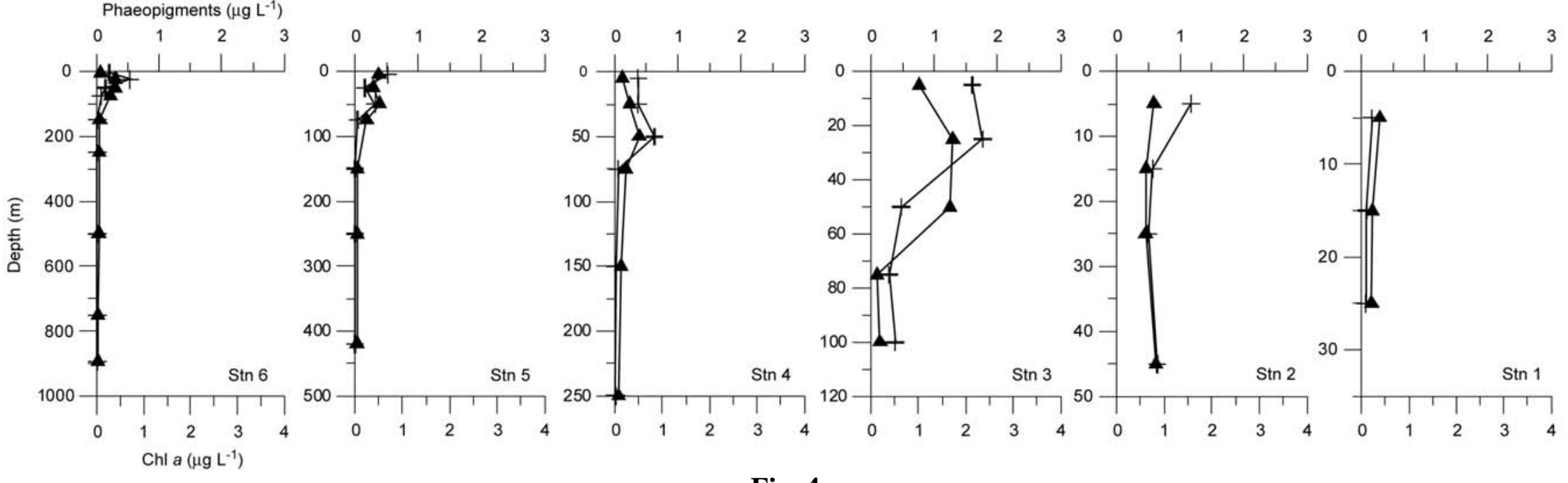

Fig. 4 


\section{Trivandrum}

Phytoplankton $\left(x 10^{3}\right.$ cells $\left.\mathrm{L}^{-1}\right)$

$\begin{array}{llllll}0 & 30 & 60 & 90 & 120 & 150\end{array}$

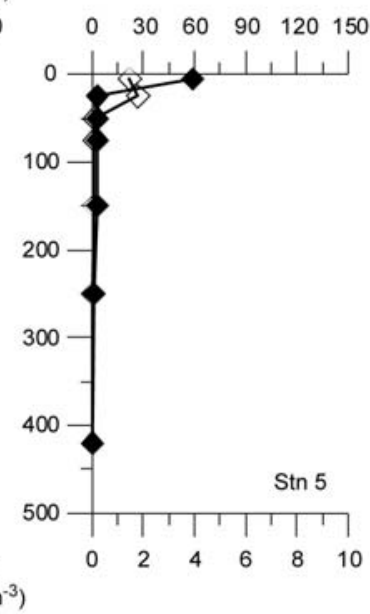

$\begin{array}{llllll}0 & 30 & 60 & 90 & 120 & 150\end{array}$


$\begin{array}{llllll}0 & 30 & 60 & 90 & 120 & 150\end{array}$

$\begin{array}{llllll}0 & 30 & 60 & 90 & 120 & 150\end{array}$
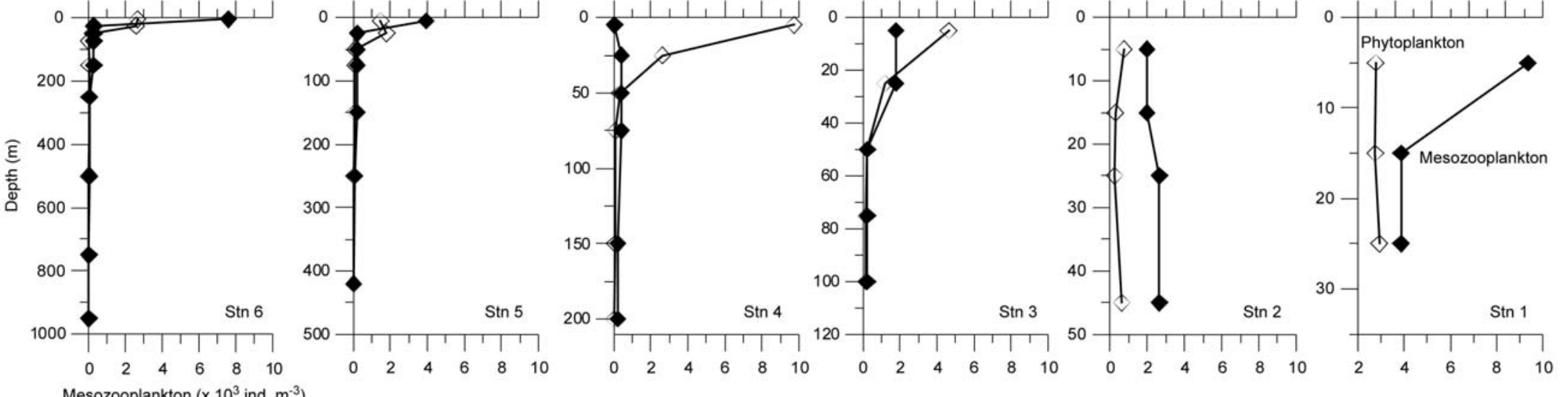

Phytoplankton $\left(\times 10^{3}\right.$ cells L $\left.{ }^{-1}\right)$
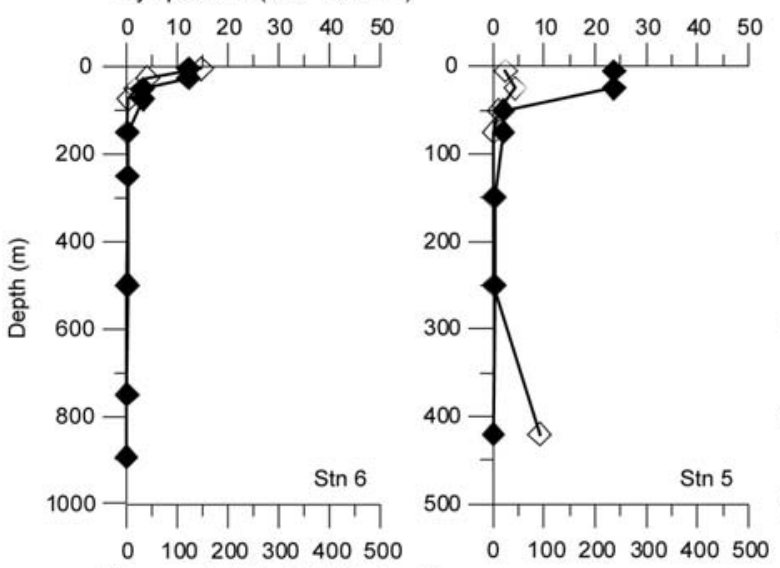

$0 \quad 100200300400500$ Mesozooplankton $\left(\times 10^{3}\right.$ ind. $\left.\mathrm{m}^{-3}\right)$

Kochi

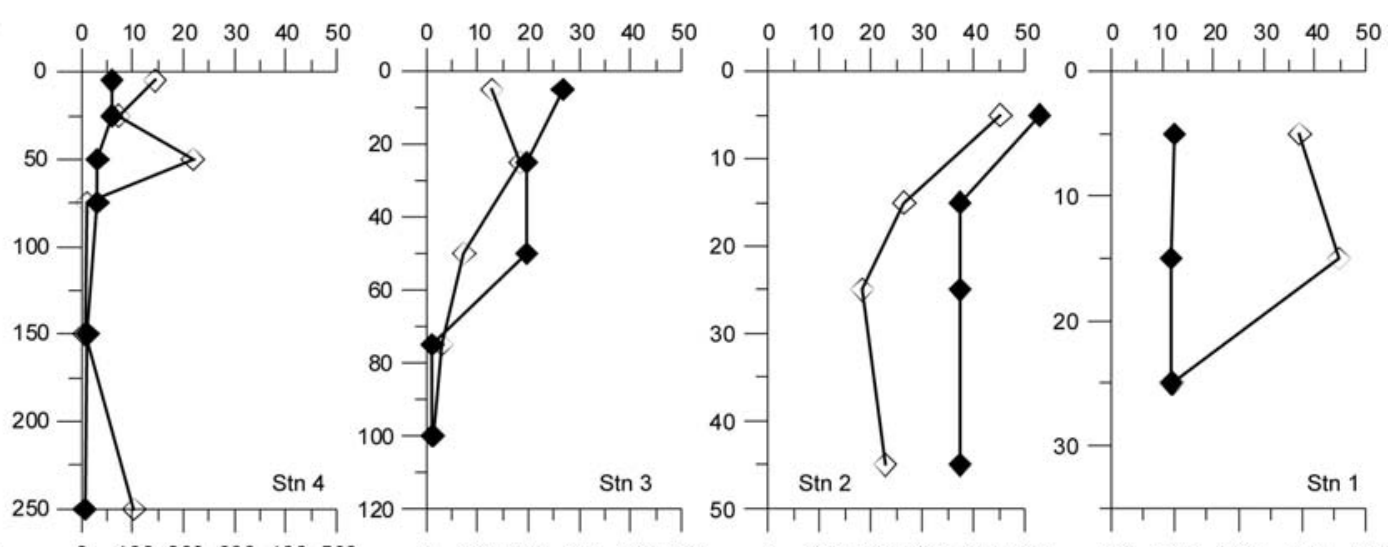

Fig. 5 


\section{Trivandrum}
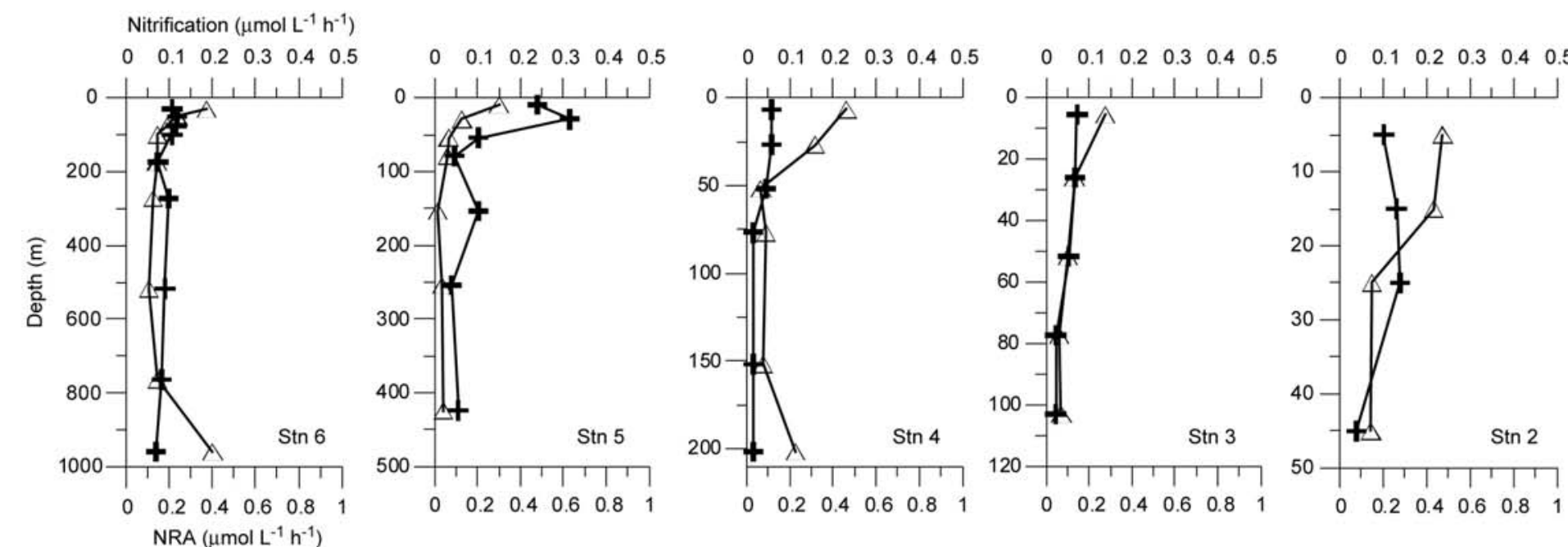

$\begin{array}{llllll}0 & 0.1 & 0.2 & 0.3 & 0.4 & 0.5\end{array}$

$\begin{array}{llllll}0 & 0.2 & 0.4 & 0.6 & 0.8\end{array}$

$\begin{array}{lllllll}0 & 0.2 & 0.4 & 0.6 & 0.8\end{array}$

$\begin{array}{llllll}0 & 0.2 & 0.4 & 0.6 & 0.8\end{array}$

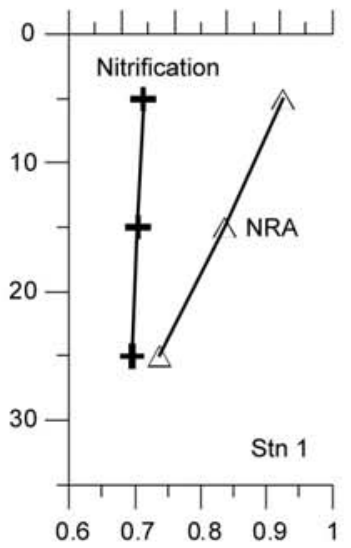

\section{Kochi}

Nitrification $\left(\mu \mathrm{mol} \mathrm{L}^{-1} \mathrm{~h}^{-1}\right)$ $\begin{array}{llllll}0 & 0.1 & 0.2 & 0.3 & 0.4 & 0.5\end{array}$ $\begin{array}{llllll}0 & 0.1 & 0.2 & 0.3 & 0.4 & 0.5\end{array}$

$\begin{array}{llllll}0 & 0.1 & 0.2 & 0.3 & 0.4 & 0.5\end{array}$ $\begin{array}{llllll}0 & 0.1 & 0.2 & 0.3 & 0.4 & 0.5\end{array}$ 00.511 .522 .533 .5 $\begin{array}{llllll}0 & 0.1 & 0.2 & 0.3 & 0.4 & 0.5\end{array}$

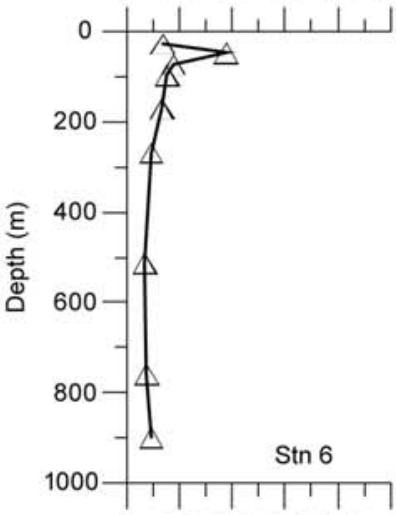

$\begin{array}{lllll}0 & 0.2 & 0.4 & 0.6 & 0.8\end{array}$ NRA $\left(\mu \mathrm{mol} \mathrm{L}^{-1} \mathrm{~h}^{-1}\right)$
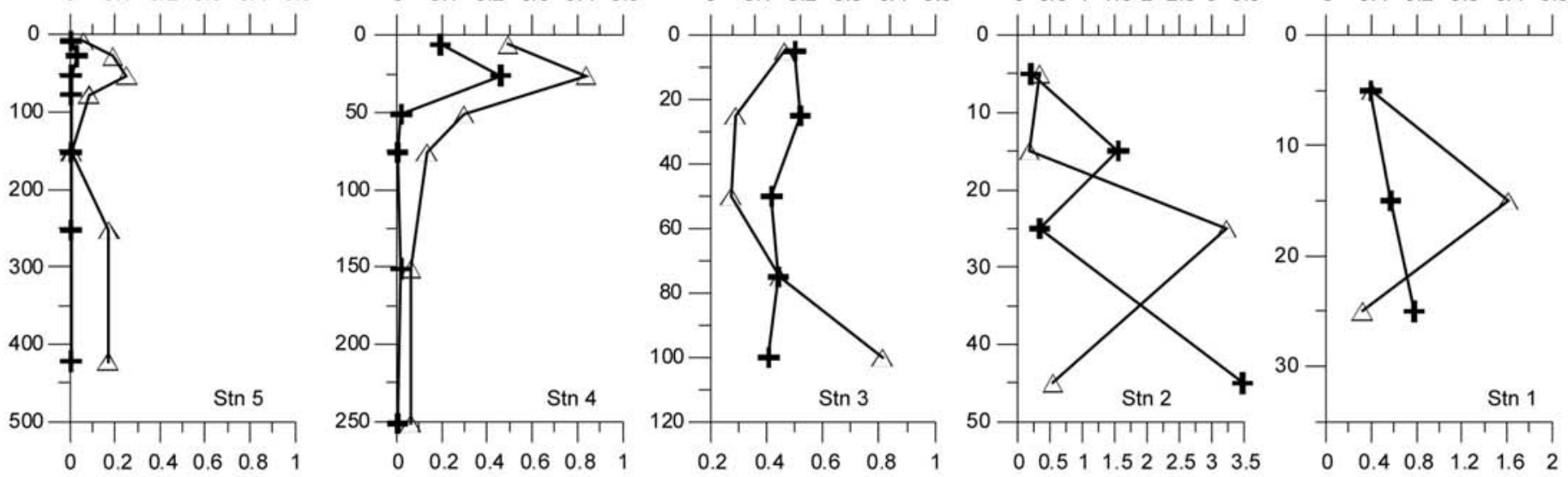

Fig. 6 


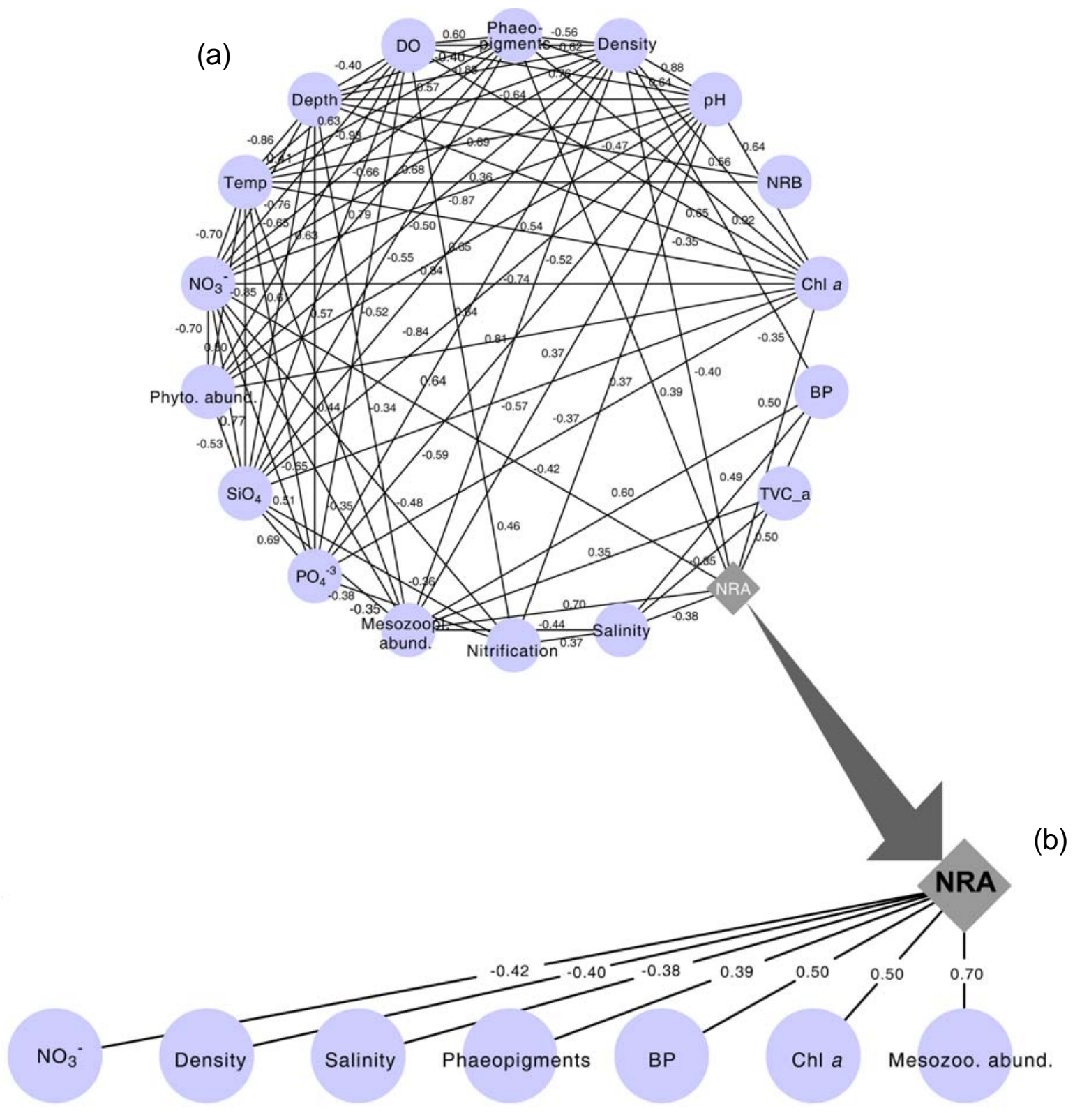

Fig. 7 

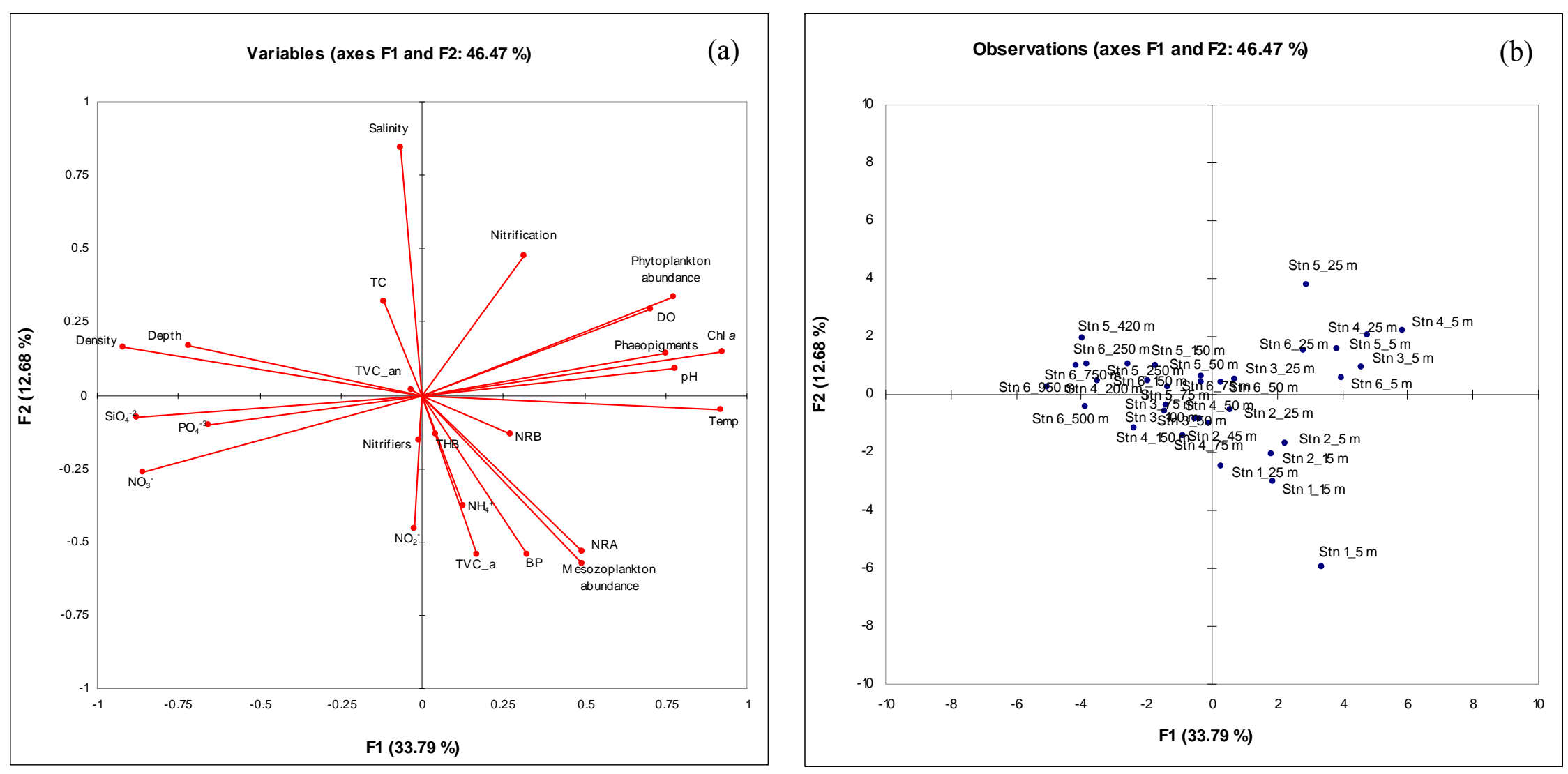

Fig. 8 
Table S1

Sampling details off Trivandrum and Kochi.

\begin{tabular}{|c|c|c|c|c|}
\hline Station no. & Latitude & Longitude & $\begin{array}{c}\text { Max. } \\
\text { depth } \\
\text { (m) }\end{array}$ & $\begin{array}{l}\text { Sampling depths } \\
\text { (m) }\end{array}$ \\
\hline \multicolumn{5}{|c|}{ Off Trivandrum } \\
\hline Station 1 & $8^{\circ} 28^{\prime} 48$ & $76^{\circ} 51^{\prime} 08$ & 39 & $5,15,25$ \\
\hline Station 2 & $8^{\circ} 30^{\prime} 45$ & $76^{\circ} 42^{\prime} 12$ & 53 & $5,15,25,45$ \\
\hline Station 3 & $8^{\circ} 27^{\prime} 04$ & $76^{\circ} 29^{\prime} 59$ & 110 & $5,25,50,75,100$ \\
\hline Station 4 & $8^{\circ} 26^{\prime} 54$ & $76^{\circ} 26^{\prime} 11$ & 205 & $5,25,50,75,150,200$ \\
\hline Station 5 & $8^{\circ} 26^{\prime} 08$ & $76^{\circ} 20^{\prime} 44$ & 510 & $5,50,75,150,250,420$ \\
\hline Station 6 & $8^{\circ} 26^{\prime} 04$ & $76^{\circ} 06^{\prime} 54$ & 970 & $5,25,50,75,150,250,500,750,950$ \\
\hline \multicolumn{5}{|l|}{ Off Kochi } \\
\hline Station 1 & $10^{\circ} 03^{\prime} 16$ & $76^{\circ} 01^{\prime} 20$ & 32 & $5,15,25$ \\
\hline Station 2 & $9^{\circ} 56^{\prime} 36$ & $75^{\circ} 51^{\prime} 14$ & 50 & $5,15,25,45$ \\
\hline Station 3 & $9^{\circ} 55^{\prime} 39$ & $75^{\circ} 38^{\prime} 06$ & 109 & $5,25,50,75,100$ \\
\hline Station 4 & $9^{\circ} 56^{\prime} 47$ & $75^{\circ} 35^{\prime} 24$ & 281 & $5,25,50,75,150,250$ \\
\hline Station 5 & $9^{\circ} 56^{\prime} 21$ & $75^{\circ} 32^{\prime} 45$ & 482 & $5,25,50,75,150,250,420$ \\
\hline Station 6 & $9^{\circ} 56^{\prime} 04$ & $75^{\circ} 29^{\prime} 57$ & 893 & $5,25,50,75,150,250,500,750,890$ \\
\hline
\end{tabular}




\section{Table S2}

Cumulative variability explained by eight factors and factor loadings of environmental variables off Trivandrum

\begin{tabular}{|c|c|c|c|c|c|c|c|c|}
\hline Variables & F1 & F2 & F3 & F4 & F5 & F6 & F7 & F8 \\
\hline Eigenvalue & 8.11 & 3.04 & 1.95 & 1.80 & 1.44 & 1.26 & 1.16 & 1.08 \\
\hline Variability (\%) & 33.79 & 12.68 & 8.13 & 7.48 & 5.98 & 5.26 & 4.84 & 4.51 \\
\hline Cumulative (\%) & 33.79 & 46.47 & 54.60 & 62.08 & 68.06 & 73.32 & 78.16 & 82.67 \\
\hline \multicolumn{9}{|l|}{ Factor loadings } \\
\hline Depth & -0.72 & 0.17 & 0.43 & -0.27 & 0.09 & 0.2 & -0.08 & 0.19 \\
\hline Temperature & 0.92 & -0.05 & -0.26 & 0.12 & -0.11 & -0.05 & 0.04 & -0.07 \\
\hline Density & -0.92 & 0.16 & 0.22 & -0.08 & 0.10 & 0.07 & 0.04 & 0.08 \\
\hline Salinity & -0.06 & 0.85 & 0.25 & 0.02 & -0.15 & 0.15 & 0.23 & -0.04 \\
\hline $\mathrm{pH}$ & 0.93 & 0.15 & -0.04 & 0.09 & -0.13 & 0.12 & 0.02 & -0.01 \\
\hline $\mathrm{DO}$ & 0.77 & 0.34 & 0.07 & -0.08 & -0.17 & 0.12 & 0.02 & 0.09 \\
\hline $\mathrm{NH}_{4}^{+}$ & 0.13 & -0.38 & -0.08 & 0.33 & -0.27 & 0.02 & 0.27 & 0.21 \\
\hline $\mathrm{NO}_{2}^{-}$ & -0.02 & -0.45 & 0.29 & 0.08 & 0.11 & 0.53 & 0.01 & 0.32 \\
\hline $\mathrm{NO}_{3}^{-}$ & -0.86 & -0.26 & -0.15 & 0.19 & -0.03 & -0.23 & -0.05 & -0.07 \\
\hline $\mathrm{PO}_{4}^{-3}$ & -0.66 & -0.10 & 0.45 & 0.01 & -0.07 & -0.06 & 0.39 & -0.18 \\
\hline $\mathrm{SiO}_{4}{ }^{-2}$ & -0.88 & -0.08 & 0.19 & -0.05 & -0.11 & -0.03 & 0.00 & -0.20 \\
\hline Chl $a$ & 0.78 & 0.09 & 0.46 & -0.08 & 0.15 & -0.20 & -0.06 & -0.04 \\
\hline Phaeopigments & 0.75 & 0.14 & 0.46 & 0.10 & 0.12 & -0.30 & -0.05 & -0.02 \\
\hline BP & 0.33 & -0.54 & 0.04 & -0.43 & 0.35 & 0.00 & 0.02 & -0.20 \\
\hline $\mathrm{TC}$ & -0.12 & 0.32 & -0.21 & -0.41 & 0.15 & -0.16 & 0.67 & -0.30 \\
\hline TVC_a & 0.17 & -0.54 & 0.03 & -0.07 & -0.48 & -0.23 & 0.29 & 0.23 \\
\hline TVC_an & -0.03 & 0.02 & 0.32 & -0.29 & -0.56 & -0.21 & 0.09 & 0.34 \\
\hline THB & 0.04 & -0.13 & 0.08 & 0.19 & 0.67 & -0.18 & 0.28 & 0.49 \\
\hline Nitrifiers & -0.01 & -0.15 & 0.46 & 0.35 & -0.15 & 0.44 & 0.00 & -0.35 \\
\hline NRB & 0.27 & -0.13 & 0.08 & 0.77 & 0.11 & 0.05 & 0.36 & -0.17 \\
\hline Nitrification & 0.32 & 0.47 & -0.35 & -0.21 & 0.05 & 0.49 & 0.26 & 0.21 \\
\hline NRA & 0.49 & -0.53 & 0.30 & -0.34 & 0.09 & 0.11 & 0.18 & -0.01 \\
\hline Phytoplankton & 0.71 & 0.30 & 0.46 & -0.01 & 0.06 & -0.18 & -0.11 & -0.06 \\
\hline Zooplankton & 0.49 & -0.57 & -0.06 & -0.40 & -0.08 & 0.24 & 0.01 & -0.24 \\
\hline
\end{tabular}

Note: F, factor; DO, dissolved oxygen; Chl $a$, chlorophyll $a$; BP, bacterial productivity; TC, total bacterial cells; TVC_a, total viable aerobic cells; TVC_an, total viable anaerobic cells; THB, total heterotrophic bacteria; NRB, nitrate reducing bacteria; NRA, nitrate reducing activity. Parameters with significant loadings within each component are highlighted in bold text. 